\title{
Microbiological and Biochemical Aspects of Camembert-Type Cheeses Depend on Atmospheric Composition in the Ripening Chamber
}

\author{
M.-N. Leclercq-Perlat, ${ }^{1}$ D. Picque, H. Riahi, and G. Corrieu \\ Unité Mixte de Recherche Génie et Microbiologie des Procédés Alimentaires, \\ Institut National de la Recherche Agronomique (INRA), F-78 850 Thiverval-Grignon, France
}

\begin{abstract}
Camembert-type cheeses were prepared from pasteurized milk seeded with Kluyveromyces lactis, Geotrichum candidum, Penicillium camemberti, and Brevibacterium aurantiacum. Microorganism growth and biochemical dynamics were studied in relation to ripening chamber $\mathrm{CO}_{2}$ atmospheric composition using 31 descriptors based on kinetic data. The chamber ripening was carried out under 5 different controlled atmospheres: continuously renewed atmosphere, periodically renewed atmosphere, no renewed atmosphere, and 2 for which $\mathrm{CO}_{2}$ was either $2 \%$ or $6 \%$. All microorganism dynamics depended on $\mathrm{CO}_{2}$ level. Kluyveromyces lactis was not sensitive to $\mathrm{CO}_{2}$ during its growth phases, but its death did depend on it. An increase of $\mathrm{CO}_{2}$ led to a significant improvement in G. candidum. Penicillium camemberti mycelium development was enhanced by $2 \% \mathrm{CO}_{2}$. The equilibrium between $P$. camemberti and $G$. candidum populations was disrupted in favor of the yeast when $\mathrm{CO}_{2}$ was higher than $4 \%$. Growth of $B$. aurantiacum depended more on $\mathrm{O}_{2}$ than on $\mathrm{CO}_{2}$. Two ripening progressions were observed in relation to the presence of $\mathrm{CO}_{2}$ at the beginning of ripening: in the presence of $\mathrm{CO}_{2}$, the ripening was fast-slow, and in the absence of $\mathrm{CO}_{2}$, it was slow-fast. The underrind was too runny if $\mathrm{CO}_{2}$ was equal to or higher than $6 \%$. The nitrogen substrate progressions were slightly related to ripening chamber $\mathrm{CO}_{2}$ and $\mathrm{O}_{2}$ levels. During chamber ripening, the best atmospheric condition to produce an optimum between microorganism growth, biochemical dynamics, and cheese appearance was a constant $\mathrm{CO}_{2}$ level close to $2 \%$.
\end{abstract}

Key words: chamber atmospheric composition, $\mathrm{CO}_{2}$ and $\mathrm{O}_{2}$, microbial and biochemical aspects, mold soft cheese ripening

\section{INTRODUCTION}

Cheese quality depends on simultaneous control of the raw material and curd production as well as pro-

Received July 19, 2005.

Accepted January 31, 2006.

${ }^{1}$ Corresponding author: perlat@grignon.inra.fr cesses and conditions of ripening. A large number of microbiological and biochemical parameters influence the ripening of soft mold-ripened cheeses like Camembert. Specific microbiological or enzymatic and biochemical aspects have already been studied (Gripon, 1993). A kinetic approach to microbial and biochemical phenomena during Camembert cheese ripening has been recently published (Leclercq-Perlat et al., 2004). These authors have established relationship between the different microbiological and biochemical changes during cheese ripening in continual renewal atmospheric conditions.

Environmental factors (temperature, hygrometry, and gaseous atmospheric composition in ripening chamber) play a determining role in microbial development and enzymatic process (van den Tempel and Nielsen, 2000; Bonaïti et al., 2004). For French mold soft cheeses, ripening temperature is kept at $12^{\circ} \mathrm{C}$. Although increasing the ripening temperature $\left(3\right.$ to $\left.4^{\circ} \mathrm{C}\right)$ is one of the easiest and most economically feasible strategies to accelerate ripening (Nunez et al., 1991), soft cheeses (in which the surface microflora has important enzymatic activities) cannot undergo substantial temperature increases without significantly modifying cheese quality (poor texture, unpleasant taste; Ramet, 2000). For mold cheeses, ripening chamber hygrometry is close to $95 \%$. Consequently, a part of the cheese water evaporates to the atmosphere leading to a decrease in cheese mass and water content (Hardy et al., 2000). If relative humidity (RH) is higher than this value, $P$. camemberti development is poor and mycelia are brown. Moreover, if $\mathrm{RH}$ is lower than $95 \%$, the water loss is excessive; therefore, the resulting cheese is too dry.

Although more data are available on packaging films and their effects on soft cheeses, little information is available on the effect of the gaseous environment in ripening chambers on the growth of microorganisms and its consequences on cheese qualities. Carbon dioxide extends the shelf life of cheeses by inhibiting mold growth (Doyon et al., 1997; Pintado and Malcata, 2000a,b; Colchin et al., 2001). However, the atmospheric composition of the ripening chamber has been shown to change the overall ripening process due to 
its effects on microorganism physiology (Kiermeier and Wolfseder, 1972a,b; Champagne et al., 2003). A low $\mathrm{O}_{2}$ concentration reduces aerobic microorganism metabolisms (Champagne et al., 2003), whereas addition of $\mathrm{CO}_{2}$ to the atmospheric composition may increase bactericidal or fungicidal effects (Taniwaki et al., 2001). Moreover, according to Champagne et al. (2003), $\mathrm{CO}_{2}$ and $\mathrm{O}_{2}$ concentrations used in experiments focused on postwrapping changes (10 to $30 \% \mathrm{CO}_{2}$ and 10 to $40 \%$ $\mathrm{O}_{2}$ ) are very different from those used in industrial ripening chambers. Little work has involved the effects of $\mathrm{CO}_{2}$ and $\mathrm{O}_{2}$ on the growth of flora throughout the ripening process and the consequences on cheese quality (Kiermeier and Wolfseder, 1972a,b; Weissenfluh and Puhan, 1987; Roger et al., 1998). Kiermeier and Wolfseder $(1972 a, b)$ have shown that oxygen consumption is correlated to $\mathrm{CO}_{2}$ production during the ripening of soft mold-ripening cheeses. Weissenfluh and Puhan (1987) and Roger et al. (1998) have shown that respiration rate of $P$. camemberti decreased when $\mathrm{O}_{2}$ partial pressure was reduced. However, the growth dynamics of strains used to ripen Camembert cheeses and their contribution to overall ripening need more investigation, in relation to time and gaseous atmospheric composition of chamber.

The aim of this study was to monitor microflora development and biochemical changes of Camembert-type cheeses throughout all the ripening process (from $d 0$ to 40), in relation to gaseous atmospheric composition of the ripening chamber (from d 0 to 16 ), especially $\mathrm{CO}_{2}$ concentration. The approach involved manufacturing a Camembert-type cheese on a pilot scale under aseptic environmental conditions, seeding with a ripening culture (K. lactis, G. candidum, P. camemberti, or B. aurantiacum). After draining and molding, the cheeses were ripened under 5 different gaseous atmospheric compositions and under controlled conditions of temperature and $\mathrm{RH}$. The effects of $\mathrm{CO}_{2}$ and $\mathrm{O}_{2}$ levels during chamber ripening were studied in relation to microbial growth, biochemical dynamics, and appearance of cheeses. The set of cheeses used here was the same as used in the companion study (Picque et al., 2006).

\section{MATERIALS AND METHODS}

\section{Biological Material, Preparation of Cultures, and Cheese Production}

The ripening cultures were Kluyveromyces lactis (GMPA collection, 448), Geotrichum candidum (Degussa, D), Penicillium camemberti (Degussa, R), and Brevibacterium aurantiacum (ATCC9175; Gavrish et al., 2004).
The preparations of $K$. lactis and B. aurantiacum were carried out as previously described in LeclercqPerlat et al. (2004). Geotrichum candidum (strain D) and $P$. camemberti (strain R) were lyophilized. Their preparation was described in Leclercq-Perlat et al., 2004. One week before use, a single tube of each starter was thawed and the viable cell concentration of each was determined. For $K$. lactis and G. candidum, this was done by surface plate counting on yeast extract glucose chloramphenicol (YEGC, Biokar, Beauvais, France) after 2 to $3 \mathrm{~d}$ of incubation at $25^{\circ} \mathrm{C}$. For $B$. aurantiacum it was determined by using a lactate medium after 5 to $6 \mathrm{~d}$ of incubation at $25^{\circ} \mathrm{C}$, and for $P$. camemberti by using YEGC containing $6 \mathrm{~g}$ of sodium chloride/100 g ( 6 to $8 \mathrm{~d} ; 20^{\circ} \mathrm{C}$ ).

Flora Danica lyophilizate (CHN11, Chr. Hansen, Arpajon, France) was the chosen mesophilic lactic acid bacteria culture. It was prepared according to LeclercqPerlat et al. (2004). Before each cheese making run, 1 aliquot of the starter was cultured at $22^{\circ} \mathrm{C}$ in $1.5 \mathrm{~L}$ of sterile skim milk for $16 \mathrm{~h}$.

The cheeses were prepared on a pilot scale under aseptic conditions in a sterilized $2-\mathrm{m}^{3}$ cheese-making chamber in which coagulation, cutting, draining, and shaping of the curds were carried out (Leclercq-Perlat et al., 2004). For each cheese-making trial, $100 \mathrm{~L}$ of milk were used to make 45 cheeses. The raw milk was obtained from the experimental farm of the Institut National Agronomique Paris-Grignon (Thiverval-Grignon, France). It was standardized at $2.9 \mathrm{~g}$ of fat/100 g by mixing skim and full-cream milk, and contained more than $3.2 \mathrm{~g}$ of protein $/ 100 \mathrm{~g}$. The cheese making and ripening of the Camembert-type cheeses was described in detail previously (Leclercq-Perlat et al., 2004). Ripening took place under the same conditions $\left(13^{\circ} \mathrm{C}\right.$ for all chamber ripening, $24 \mathrm{~h}$ at $85 \% \mathrm{RH}$, then under defined RH from d 2 to 14 , and thereafter at $85 \%$ $\mathrm{RH})$ except for $\mathrm{RH}(95 \pm 2 \%$ instead of $93 \pm 1 \%)$ and the wrapping time (on d 16 instead of d 14). However, the system used to maintain $\mathrm{RH}$ in the chamber in previous experiments was changed to account for salt evaporation. Indeed, in this study, $\mathrm{RH}$ was controlled without salt baths (potassium nitrate, $\mathrm{KNO}_{3}$ in saturation) because during the preliminary $\mathrm{CO}_{2}$ runs, a significant quantity of water evaporated into the atmosphere and was not absorbed by the salt baths. Thus, a system based on the principle of cold point, involving a cooling and heating system plunged into a water tank, was used.

From d 0 to 16 , cheeses were ripened in chamber under 5 controlled atmospheres as described in detail I the companion article (Picque et al., 2006): 1) continuously renewed atmosphere (CRA) under which $\mathrm{CO}_{2}$ and $\mathrm{O}_{2}$ levels remained at 0 and $21 \%$, respectively; 2) period- 
ically renewed atmosphere (PRA) under which the ripening chamber was sealed but each day, if necessary, the $\mathrm{CO}_{2}$ concentration was decreased to $2 \%$ by air injection $\left(\mathrm{O}_{2}\right.$ decreased to 17 to $\left.18 \%\right)$; 3$)$ no renewed atmosphere (NRA) under which the chamber was sealed during chamber ripening (accumulation of $\mathrm{CO}_{2}$ up to $20 \%$, disappearance of $\left.\mathrm{O}_{2}\right)$; 4) $\mathrm{CO}_{2}$ concentration maintained at $2 \%$ from d 0 to 16 , with $\mathrm{O}_{2}$ close to 17 to $18 \%$ $\left(\mathbf{2 C O}_{2}\right)$; and 5) $\mathrm{CO}_{2}$ concentration kept constant at $6 \%$ from d 0 to 16 , with $\mathrm{O}_{2} \sim 12$ to $13 \%\left(\mathbf{6 C O}_{2}\right)$.

Each controlled atmosphere trial was carried out in duplicate, except NRA. Only one run was carried under NRA because the rind color was slightly brown, and cheeses exhibited another major flaw: the surface was greasy and irregular; the underrind was completely runny.

For all runs, the effects of $\mathrm{CO}_{2}$ and $\mathrm{O}_{2}$ on the microbiological and biological aspects of cheeses were recorded. Under PRA and NRA, $\mathrm{CO}_{2}$ concentration increased in relation to time and it was calculated by determining the average for each phase of the timeline described below.

For each run, all the cheeses were turned on $\mathrm{d} 5$. Between d 0 and 16, 1 cheese was removed daily for analysis. On d 16, all remaining cheeses were wrapped, and left to finish ripening at $4^{\circ} \mathrm{C}$ under unknown $\mathrm{RH}$ until d 40. During this period (d 16 to 40), 1 cheese was removed weekly for analysis.

\section{Microbial Counts and Biochemical Analysis}

These analyses were carried out as previously described by Leclercq-Perlat et al. (2004).

Viable cell counts of $K$. lactis and of $G$. candidum in both the rind and the core were measured by counting in YEGC dishes $\left(25^{\circ} \mathrm{C} ; 2\right.$ to $\left.3 \mathrm{~d}\right)$. Spores of $P$. camemberti in the rind were determined by counting on YEGC medium containing $60 \mathrm{~g}$ of $\mathrm{NaCl} / \mathrm{L}$ to limit $G$. candidum growth $\left(20^{\circ} \mathrm{C}, 6\right.$ to $\left.8 \mathrm{~d}\right)$. Viable cells of $B$. aurianticum in the rind were determined on amphotericin-containing lactate agar $\left(25^{\circ} \mathrm{C}, 7 \mathrm{~d}\right)$.

Dry matter and $\mathrm{pH}$ as well as lactose and lactate concentrations in both the rind and the core were measured. Nitrogen fractions [total N, acid-soluble nitrogen (ASN), NPN, and free ammonium concentrations] were measured for the rind only. The thickness of the cheese creamy underrind was measured using the first $15 \mathrm{~mm}$ at 6 points on each face. Then, the arithmetic average of these 12 measurements was calculated. The appearance of the cheese (microorganism cover, surface appearance, and texture of the underrind) was estimated as proposed by Bonaïti et al. (2004).

\section{Statistical Analyses}

The evolutions of microbiological concentrations, biochemical kinetics, and the cheese appearance during the entire ripening period ( $\mathrm{d} 0$ to 40 ) were described by 2 or 3 descriptors. Except for $K$. lactis, the descriptors were determined by a Weibull model (using Statistica for Windows, Statsoft, Maisons-Alfort, France). The descriptors for K. lactis were calculated by linear regression. All the statistical tests were carried out using the 95\% confidence level $(P<0.05)$. The reproducibility of the microbiological (viable cell counts) and the biochemical measurements (carbon substrate concentrations, $\mathrm{pH}, \mathrm{DM}$, nitrogen fractions, and underrind thickness) were studied according to Leclercq-Perlat et al. (2004). This analysis showed that 1 ) the hypotheses of equality of the means were satisfactory $(1-\alpha=0.95)$, and 2) the risks of a false interpretation $(\alpha)$ were less than 0.05 . For all statistical analyses, explained variance (Weibull modeling; R) or correlation coefficient (linear regression; R) was between 0.90 and 0.99 , at a $95 \%$ confidence level, except for NPN maximal rate of PRA and $6 \mathrm{CO}_{2}$. For this descriptor, explained variance $(\mathrm{R})$ was between 0.81 and 0.83 at a $95 \%$ confidence level. If $R$ was higher than 0.9 , the descriptor was highly significant, and if it was between 0.81 and 0.90 , the descriptor was simply significant.

For each single measurement, and each sampling day, a 1-way ANOVA was used to determine the influence of $\mathrm{CO}_{2}$; ANOVA was carried out with NewmanKeuls test at a $P$-value of 0.01 .

\section{RESULTS}

\section{Microbiological and Biochemical Behavior Under CRA}

Under CRA conditions, during which total air volume was renewed every $2 \mathrm{~h}$, no accumulation of $\mathrm{CO}_{2}$ was observed and $\mathrm{O}_{2}$ level remained constant at $21 \%$ (Picque et al., 2006). These CRA runs were the reference $\mathrm{CO}_{2}$ treatment. The effects of $\mathrm{CO}_{2}$ and $\mathrm{O}_{2}$ on microbiological and biochemical parameters and appearance of cheeses were compared with those obtained under the other 4 atmospheric conditions.

\section{Microbiological Changes in Ripening Cheeses}

For the average of 2 runs, the $\log _{10}$ of ripening microorganism counts of the rind vs. time were similar to those described in a previous study (Leclercq-Perlat et al., 2004). In the core, the overall changes in $K$. lactis and $G$. candidum concentrations were similar to those in the rind. However, their concentrations were around 250 times lower than in the rind (data not shown). As 
expected, $P$. camemberti and B. aurantiacum did not grow in the core.

Three phases were apparent in the timeline of $K$. lactis growth and several kinetic descriptors were calculated (Table 1). Firstly, between d 0 and 5, the specific growth rate $\left(\mu_{\max }\right)$ during the exponential phase was $0.46 \pm 0.04 \mathrm{~d}^{-1}$ and the associated generation time was close to $1.5 \mathrm{~d}$. Secondly, from d 5 to 19 , the viable count $\left(\mathrm{X}_{\max }\right)$ remained constant, close to $4 \times 10^{7} \mathrm{cfu} / \mathrm{g}$. Thirdly, after d 19 and until d 40, the viable $K$. lactis count diminished slowly and exponentially with a specific death rate $\left(D_{\max }\right)$ equal to $0.100 \pm 0.007 \mathrm{~d}^{-1}$.

Three phases were apparent in the timeline of $G$. candidum growth (Figure 1A, Table 1). Firstly, growth of $G$. candidum was measurable only after d 3 (lag phase). The second phase, between $\mathrm{d} 4$ and 8 , had a maximum specific growth rate $\left(\mu_{\max }\right)$ on $\mathrm{d} 6$ equal to $0.7 \pm 0.2 \mathrm{~d}^{-1}$ and associated generation time was about $1.0 \mathrm{~d}$. In the third phase (stationary phase), between $\mathrm{d}$ 9 and 40, the maximal viable count remained constant at $\sim 1 \times 10^{7} \mathrm{cfu} / \mathrm{g}$ of DM.

Viable $P$. camemberti spore counts in the rind were close to $10^{4} \mathrm{cfu} / \mathrm{g}$ of DM during the first $6 \mathrm{~d}$ of ripening (Figure 1B, Table 1). Then, from d 6 to 19, growth was slow and close to exponential with a specific growth rate $\left(\mu_{\max }\right)$ of $0.23 \pm 0.05 \mathrm{~d}^{-1}$ occurring on $9 \pm 3 \mathrm{~d}$ (Table 1). After d 20 and until d 40, these spore concentrations remained constant, close to $7.5 \times 10^{5} \mathrm{cfu} / \mathrm{g}$ of $\mathrm{DM}$. Because the sampling technique destroyed the mycelia, only visual observation of the surface was possible; $P$. camemberti mycelia were seen from $d 4$. Between $d 5$ and 12 , the mycelia grew and uniformly covered the entire cheese surface by d 12 .

Three phases were apparent in the timeline of $B$. aurantiacum growth as previously shown (LeclercqPerlat et al., 2004); B. aurantiacum counts in the rind remained nearly constant (at $6.3 \times 10^{4} \mathrm{cfu} / \mathrm{g}$ of DM) during the first $10 \mathrm{~d}$ of ripening. Between d 12 and 19, this species grew exponentially with a specific growth rate $\left(\mu_{\max }\right)$ equal to $0.46 \pm 0.07 \mathrm{~d}^{-1}$ and the time taken to reach $\mu_{\max }$ reached $15 \pm 1 \mathrm{~d}$ (Table 1 ). From d 20 to $40, B$. aurantiacum counts remained constant, close to $3.4 \times 10^{8} \mathrm{cfu} / \mathrm{g}$.

\section{Biochemical Changes in Ripening Cheeses}

$\mathrm{pH}$ dynamics under CRA conditions were similar to those observed in previous studies (Leclercq-Perlat et al., 2004) and showed 3 phases. Firstly, between d 0 and $3, \mathrm{pH}$ values remained constant at $4.60 \pm 0.06$. Secondly, between $\mathrm{d} 5$ and $7, \mathrm{pH}$ values increased strongly with a deacidification rate $\left(\mathrm{V}_{\max }\right)$ close to 1.3 $\mathrm{pH}$ unit/d, reaching 7.5 on $\mathrm{d} 7$. During this phase, rind $\mathrm{pH}$ presented an important standard deviation due to important differences between the 2 sides of each cheese. Thirdly, from d 7 to 40 , rind $\mathrm{pH}$ did not significantly change, remaining close to $7.6 \pm 0.2$. The $\mathrm{pH}$ of the core changed slowly during ripening (Table 2). From $\mathrm{d} 0$ to 8 , the $\mathrm{pH}$ remained constant at $4.65 \pm 0.05$, and it increased slightly until the end of ripening, reaching $7.0 \pm 0.2$ on $\mathrm{d} 40$.

Lactose and lactate concentrations ( $\mathrm{mmol} / \mathrm{kg}$ of $\mathrm{DM})$ in the rind and in the core under CRA conditions were similar to those obtained by Leclercq-Perlat et al. (2004). On d 0, the lactose in the rind or the core was around 80 and $100 \mathrm{mmol} / \mathrm{kg}$ of DM, respectively. Lactose concentrations decreased quickly with a maximal consumption rate $\left(\mathbf{C}_{\mathbf{L O}}\right)$ in the rind close to $18 \mathrm{mmol} /$ $\mathrm{kg}$ of DM per $\mathrm{d}$ and with a lactose rate $\left(\mathbf{D}_{\mathrm{LO}}\right)$ decreasing to $12 \mathrm{mmol} / \mathrm{kg}$ of DM per d in the core (Table 3). Lactose concentration was negligible on d 6 in the rind and on d 10 in the core.

Between d 0 and 4, lactate concentrations increased in the rind and in the core due to the postacidification phenomenon. On d 4, lactate concentration was maxi$\mathrm{mal}$, and close to 450 and $500 \mathrm{mmol} / \mathrm{kg}$ of DM for the rind and core, respectively. On d 4 and until d 9 (rind) or d 16 (core), lactate concentration decreased rapidly with a decreasing rate close $\left(\mathbf{C}_{\mathbf{L T}}\right)$ to $106 \mathrm{mmol} / \mathrm{g}$ of DM per $\mathrm{d}$ for the rind and $\left(\mathbf{D}_{\mathbf{L T}}\right)$ close to $32 \mathrm{mmol} / \mathrm{kg}$ of DM per $\mathrm{d}$ for the core (Table 3). Lactate concentration became negligible on $d 16$ (wrapping) for the rind and on $\mathrm{d} 40$ for the core.

The descriptors of changes in ASN and NPN indexes as well as $\mathrm{NH}_{3}$ concentrations of the rind during all the ripening ( 0 to 40 ) are shown in Table 4 . The ASN index remained constant at $18 \pm 4 \mathrm{~g}$ of ASN/100 $\mathrm{g}$ of total $\mathrm{N}(\%)$ during the first $3 \mathrm{~d}$ of ripening. Then, it increased from d 3 to $d 6$ at a maximal rate of $26 \% / d$, reaching $100 \%$ on d 8 . Afterwards, and until d 40, ASN remained constant at $100 \%$.

The NPN index remained constant at almost $4 \mathrm{~g}$ of NPN/100 g of total N (\%) during the first $4 \mathrm{~d}$ of ripening. Between $\mathrm{d} 4$ and 7 , it increased at a maximal rate of $16.0 \% / d$, reaching about $44 \%$ on $d 7$. Afterwards, and until d 40, it increased slowly, reaching about $50 \%$ on d 40 (Figure 2A; Table 4).

Ammonia concentrations remained at about $1 \mathrm{~g}$ of $\mathrm{NH}_{3} / \mathrm{kg}$ of $\mathrm{DM}$ during the first $5 \mathrm{~d}$ of ripening. After $\mathrm{d}$ 5 , and until $\mathrm{d} 16, \mathrm{NH}_{3}$ concentrations increased at a maximal rate of $1.13 \mathrm{~g}$ of $\mathrm{NH}_{3} / \mathrm{kg}$ of $\mathrm{DM}$ per $\mathrm{d}$ to reach about $13.5 \mathrm{~g}$ of $\mathrm{NH}_{3} / \mathrm{kg}$ of DM. After d 16 and until the end of ripening, it remained nearly constant at $14 \mathrm{~g}$ of $\mathrm{NH}_{3} / \mathrm{kg}$ of DM (Figure 2B, Table 4).

\section{Changes in Cheese Appearance}

The rind color of the cheeses provided information about the ripening and microorganism dynamics. From 
Table 1. Kinetic descriptors of microorganism dynamics in relation to atmospheric conditions during chamber ripening of a Camemberttype cheese ${ }^{1}$

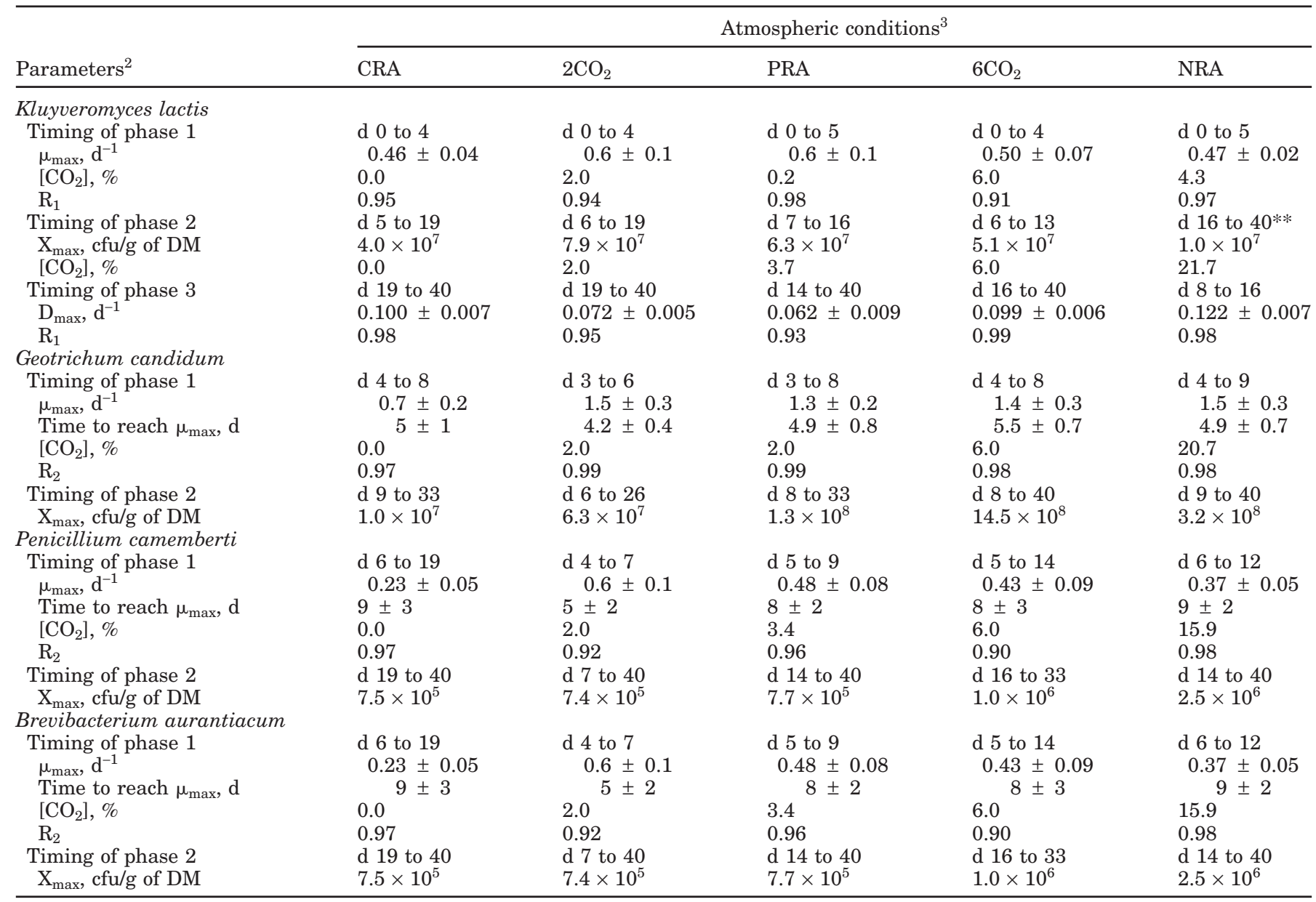

${ }^{1}$ Values are the means of duplicate runs carried out under the same conditions; only a single run was carried out under NRA conditions.

${ }^{2}$ Parameters: $\mu_{\max }=$ maximum specific growth rate determined by modelling; $\left[\mathrm{CO}_{2}\right]=\mathrm{CO}_{2}$ concentration; $\mathrm{R}_{1}=$ linear regression coefficient; $\mathrm{X}_{\max }=$ mean cell concentration obtained under stationary growth phase; $\mathrm{D}_{\max }=$ maximal death rate; $R_{2}=$ explained variance of Weibull modelling; phase 1 = exponential growth; phase 2 = stationary phase.

${ }^{3}$ Atmospheric conditions: $\mathrm{CRA}=$ continuously renewed atmosphere under which $\mathrm{CO}_{2}$ and $\mathrm{O}_{2}$ levels remained at 0 and $21 \%$, respectively; PRA = periodically renewed atmosphere under which the ripening chamber was sealed but each day, if necessary, the $\mathrm{CO}_{2}$ concentration was decreased to $2 \%$ by air injection $\left(\mathrm{O}_{2}\right.$ decreased to 17 to $\left.18 \%\right)$;RA = no renewed atmosphere under which the chamber was sealed during chamber ripening (accumulation of $\mathrm{CO}_{2}$ up to $20 \%$, disappearance of $\mathrm{O}_{2}$ ); $2 \mathrm{CO}_{2}=\mathrm{CO}_{2}$ concentration maintained at $2 \%$ from d 0 to 16, with $\mathrm{O}_{2}$ close to 17 to $18 \%$; and $6 \mathrm{CO}_{2}=\mathrm{CO}_{2}$ concentration kept constant at $6 \%$ from d 0 to 16 , with $\mathrm{O}_{2} \sim 12$ to $13 \%$.

** = mean value obtained during the stationary phase.

d 0 to 1 , color was uniformly white and bright. From d 1 to 5 , cheeses became slightly cream colored and extremely dull due to growth of $K$. lactis. On d 4 , growth of $P$. camemberti aerial mycelia was observed. These mycelia began to grow in spots on the aired face of cheeses. From d 10 to 16 (wrapping), rind color was white with short and uniform mycelium growth typical of $P$. camemberti. After d 10, the rind was close to 3 $\mathrm{mm}$ thick and the surface color remained white. However, on $d 40$, the outer circumference of each side of the cheeses was light cream colored, but no relationship with $B$. aurantiacum growth could be established.
The thickening of the underrind in relation to ripening time provided information about the ripening level because the underrind was linked to proteolysis and lipolysis dynamics (Table 5, Figure 3). Between d 0 and 5 , the underrind thickness values remained negligible. Between $\mathrm{d} 5$ and 14, thickness increased slightly, reaching about $2.0 \mathrm{~mm}$ on d 16 . After $\mathrm{d} 16$ and until the end of ripening (d 40), thickness greatly increased with a maximal rate $\left(\mathrm{V}_{\max }\right)$ equal to $0.63 \pm 0.09 \mathrm{~mm} / \mathrm{d}$ (Table 5 ), which occurred on $d 27$. On $d 40$, the underrind thickness was maximal and corresponded to about half the thickness of the cheese $(15 \mathrm{~mm})$. 

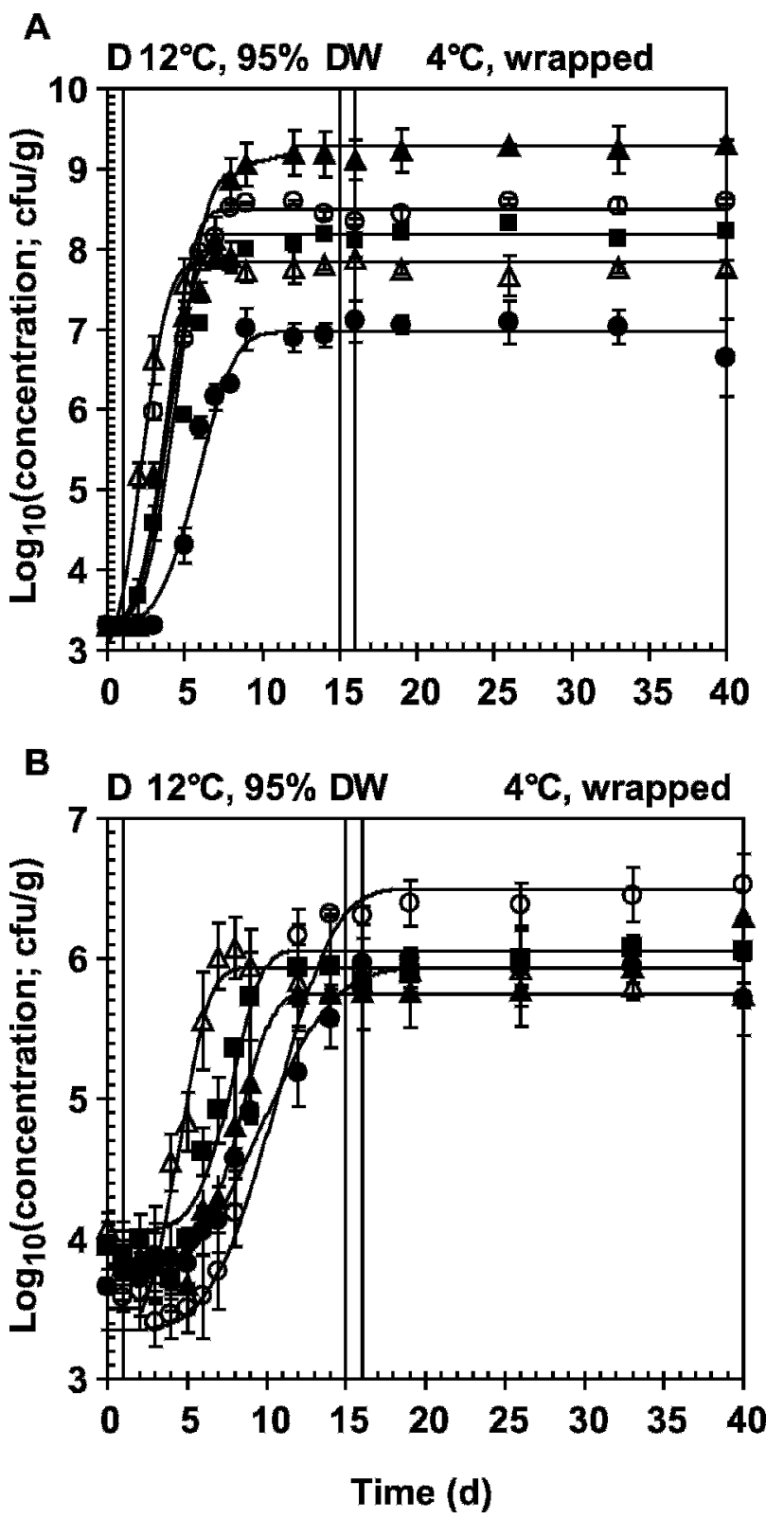

Figure 1. Changes in A) Geotrichum candidum cell concentration and B) Penicillium camemberti spore concentration in the rind in relation to ripening time (from d 0 to 40). All progressions were made using Weibull modeling. $\mathrm{D}=$ surface drying period (relative humidity $=85 \%) ; \mathrm{W}=$ wrapping on d 16 . Except under NRA, each progression vs. time and its standard deviation (error bars) represent the mean of 2 runs carried out under conditions of CRA ( $), 2 \mathrm{CO}_{2}$ $(\Delta)$, PRA ( $\mathbf{\square}), 6 \mathrm{CO}_{2}(\boldsymbol{\Delta})$, and NRA $(\bigcirc)$ in the ripening chamber (from d 0 to $16,12^{\circ} \mathrm{C}$, relative humidity $=95 \%$ ). $-=$ modeling results. Atmospheric conditions: CRA = continuously renewed atmosphere under which $\mathrm{CO}_{2}$ and $\mathrm{O}_{2}$ levels remained at 0 and $21 \%$, respectively; PRA = periodically renewed atmosphere under which the ripening chamber was sealed but each day, if necessary, the $\mathrm{CO}_{2}$ concentration was decreased to $2 \%$ by air injection $\left(\mathrm{O}_{2}\right.$ decreased to 17 to $\left.18 \%\right)$; $\mathrm{NRA}=$ no renewed atmosphere under which the chamber was sealed during chamber ripening (accumulation of $\mathrm{CO}_{2}$ up to $20 \%$, disappearance of $\left.\mathrm{O}_{2}\right) ; 2 \mathrm{CO}_{2}=\mathrm{CO}_{2}$ concentration maintained at $2 \%$ from d 0 to 16 , with $\mathrm{O}_{2}$ close to 17 to $18 \%$; and $6 \mathrm{CO}_{2}=\mathrm{CO}_{2}$ concentration kept constant at $6 \%$ from d 0 to 16 , with $\mathrm{O}_{2} \sim 12$ to $13 \%$.

\section{Influence of Gaseous Atmospheric Composition on Ripening Dynamics}

Microbiological Changes in Ripening Cheeses. Table 1 lists the 3 descriptors $\left(\mu_{\max }, \mathrm{X}_{\max }, \mathrm{D}_{\max }\right)$ for growth of $K$. lactis as well as the 2 descriptors $\left(\mu_{\max }\right.$, $\mathrm{X}_{\max }$ ) for growth of $G$. candidum, $P$. camemberti spores, and $B$. aurantiacum, in relation to ripening chamber $\mathrm{CO}_{2}$ concentration. Under PRA and NRA conditions, $\mathrm{CO}_{2}$ concentration increased in relation to time, and it was calculated by determining the average for each phase of the time line described below.

Whatever the $\mathrm{CO}_{2}$ concentration, $K$. lactis growth began on $\mathrm{d} 0$ and finished between $\mathrm{d} 4$ (CRA, NRA, and $\left.6 \mathrm{CO}_{2}\right)$ and d $6\left(2 \mathrm{CO}_{2}, \mathrm{PRA}\right.$, Table 1$)$. The mean specific growth rate $\left(\mu_{\max }\right)$ was statistically $0.5 \pm 0.1 \mathrm{~d}^{-1}$. The concentration of $\mathrm{CO}_{2}$ in the chamber atmosphere did not have any statistically significant effects on $\mu_{\max }$ and $\mathrm{X}_{\text {max }}$. Except under NRA conditions, the death phase began around the end of chamber ripening ( $d 14$ to 19) and it finished on $d 40$. It was characterized by mean specific death rates between 0.062 and $0.10 \mathrm{~d}^{-1}$. Under NRA, the $K$. lactis death period was completely shifted in relation to ripening time. It took place between $\mathrm{d} 8$ and 16 , when $\mathrm{CO}_{2}$ completely replaced $\mathrm{O}_{2}$, and out of all the atmospheric conditions, the death rate of $K$. lactis was the highest $(0.122 \pm 0.007$ per $d)$ in this case (NRA). The absence of $\mathrm{O}_{2}$ probably explained this highest rate and earliest mortality. The overall dynamics of $K$. lactis depended on $\mathrm{CO}_{2}$ concentration, and in particular, the timing of the death phase.

The ANOVA (data not shown) showed no effect of $\mathrm{CO}_{2}$ concentration on dynamics of $K$. lactis.

Regardless of $\mathrm{CO}_{2}$ concentration, growth of $G$. candidum vs. time exhibited the same overall changes (Figure $1 \mathrm{~A})$. Concentration of $\mathrm{CO}_{2}$ present in the ripening chamber showed very significant effects on $G$. candidum growth descriptors $\left(\mu_{\max }, \mathrm{X}_{\max }\right.$; Table 1$)$. Maximal growth rates of $G$. candidum were about twice as high as those obtained under CRA conditions $(0 \%$ of $\mathrm{CO}_{2}$ ), but the associated time (time for $\mu_{\max }$ ) was about the same value due to standard deviation. The lowest $\mathrm{X}_{\max }$ value was obtained under CRA. Under $6 \mathrm{CO}_{2}$ conditions the maximal concentration of $G$. candidum rose to $145 \times 10^{7} \mathrm{cfu} / \mathrm{g}$. However, when $\mathrm{CO}_{2}$ concentration was higher than $6 \%$ under NRA, G. candidum $\mathrm{X}_{\max }(32$ $\times 10^{7} \mathrm{cfu} / \mathrm{g}$ ) was reduced.

Analysis of variance (Table 6) confirmed that these dynamics were the lowest under CRA. The presence of $\mathrm{CO}_{2}$ during chamber ripening promoted $G$. candidum growth, and after wrapping (d 16) the effect of $\mathrm{CO}_{2}$ on cell concentrations $\left(\mathrm{X}_{\max }\right)$ was obvious: $\mathrm{X}_{\max }$ presented a maximum in relation to $\mathrm{CO}_{2}$ concentration (Figure $1 \mathrm{~A}$ ). 
Table 2. Values of kinetic descriptors (obtained from Weibull modeling) of rind $\mathrm{pH}$ dynamics in relation to atmospheric conditions during chamber ripening (from d 0 to 16) of a Camembert-type cheese ${ }^{1}$

\begin{tabular}{llllll}
\hline & \multicolumn{5}{c}{ Atmospheric conditions $^{3}$} \\
\cline { 2 - 6 } Parameters $^{2}$ & $\mathrm{CRA}$ & $2 \mathrm{CO}_{2}$ & $\mathrm{PRA}$ & $6 \mathrm{CO}_{2}$ & $\mathrm{NRA}$ \\
\hline Timing of phase 1 & $\mathrm{~d} 5$ to 7 & $\mathrm{~d} 5$ to 7 & $\mathrm{~d} 5$ to 7 & $\mathrm{~d} 5$ to 7 & $\mathrm{~d} 5$ to 7 \\
$\mathrm{~V}_{\max }, \mathrm{pH}$ unit/d & $1.3 \pm 0.1$ & $1.5 \pm 0.1$ & $1.2 \pm 0.2$ & $1.26 \pm 0.06$ & $1.18 \pm 0.09$ \\
{$\left[\mathrm{CO}_{2}\right], \%$} & 0.0 & 2.0 & 3.3 & 6.0 & 5.4 \\
Timing of phase 2 & $\mathrm{~d} 7$ to 40 & $\mathrm{~d} 7$ to 40 & $\mathrm{~d} 9$ to 40 & $\mathrm{~d} 8$ to 40 & $\mathrm{~d} 9$ to 40 \\
$\mathrm{pH}_{\max }$ & $7.6 \pm 0.2$ & $7.9 \pm 0.1$ & $7.8 \pm 0.1$ & $7.8 \pm 0.3$ & $7.6 \pm 0.1$ \\
{$\left[\mathrm{CO}_{2}\right], \%$} & 0.0 & 2.0 & 3.7 & 6.0 & 19.8 \\
$\mathrm{R}$ & 0.983 & 0.982 & 0.984 & 0.980 & 0.983 \\
\hline
\end{tabular}

${ }^{1}$ Values are the means of duplicate runs carried out under the same conditions; only a single run was carried out under NRA conditions.

${ }^{2}$ Parameters: $\mathrm{V}_{\max }=$ maximal rate; $\left[\mathrm{CO}_{2}\right]=\mathrm{CO}_{2}$ concentration; $\mathrm{pH}_{\max }=$ maximal $\mathrm{pH}$ value reached; phase $1=$ increasing phase; phase $2=$ constant phase.

${ }^{3}$ Atmospheric conditions: CRA = continuously renewed atmosphere under which $\mathrm{CO}_{2}$ and $\mathrm{O}_{2}$ levels remained at 0 and $21 \%$, respectively; PRA = periodically renewed atmosphere under which the ripening chamber was sealed but each day, if necessary, the $\mathrm{CO}_{2}$ concentration was decreased to $2 \%$ by air injection $\left(\mathrm{O}_{2}\right.$ decreased to 17 to $\left.18 \%\right)$; NA = no renewed atmosphere under which the chamber was sealed during chamber ripening (accumulation of $\mathrm{CO}_{2}$ up to $20 \%$, disappearance of $\mathrm{O}_{2}$ ); $2 \mathrm{CO}_{2}=\mathrm{CO}_{2}$ concentration maintained at $2 \%$ from d 0 to 16 , with $\mathrm{O}_{2}$ close to 17 to $18 \%$; and $6 \mathrm{CO}_{2}=\mathrm{CO}_{2}$ concentration kept constant at $6 \%$ from d 0 to 16 , with $\mathrm{O}_{2} \sim 12$ to $13 \%$.

Changes in $\mathrm{CO}_{2}$ concentration induced changes in maximal sporulation rate ( $\mu_{\max }$; Figure $1 \mathrm{~B}$, Table 1 ). Indeed, out of all the atmospheric conditions, the highest maximal sporulation rate value was under $2 \mathrm{CO}_{2}$. The highest $\mathrm{CO}_{2}$ concentration (NRA) had a significant effect on the maximal $\mathrm{X}_{\max }$ value, which reached about $2.5 \times 10^{6}$ spores/g (around 3 times higher than for the other conditions).
Analysis of variance (Table 6) confirmed that for $P$. camemberti sporulation, 1) CRA and $6 \mathrm{CO}_{2}$ showed the same progressions; 2) $2 \mathrm{CO}_{2}$ runs had the highest progressions between $\mathrm{d} 3$ and 16 ; and 3$) \mathrm{PRA}\left(\mathrm{CO}_{2}\right.$ between 2 and $8 \%$ ) was intermediate between $2 \mathrm{CO}_{2}, 6 \mathrm{CO}_{2}$, and NRA.

Regardless of $\mathrm{CO}_{2}$ concentration, $B$. aurantiacum counts presented several progressions vs. time (data

Table 3. Values of kinetic descriptors of carbon substrate in relation to atmospheric conditions during chamber ripening (from $\mathrm{d} 0$ to 16 ) of a Camembert-type cheese ${ }^{1}$

\begin{tabular}{|c|c|c|c|c|c|}
\hline \multirow[b]{2}{*}{ Parameters $^{2}$} & \multicolumn{5}{|c|}{ Atmospheric conditions ${ }^{3}$} \\
\hline & CRA & $2 \mathrm{CO}_{2}$ & PRA & $6 \mathrm{CO}_{2}$ & NRA \\
\hline Timing of phase 1 & $\mathrm{~d} 0$ to 6 & d 0 to 6 & $\mathrm{~d} 1$ to 7 & d 0 to 7 & d 3 to 8 \\
\hline $\mathrm{C}_{\mathrm{LO}}, \mathrm{mmol} / \mathrm{kg}$ of $\mathrm{DM}$ per $\mathrm{d}$ & $18 \pm 2$ & $16 \pm 1$ & $18 \pm 1$ & $14 \pm 2$ & $22 \pm 3$ \\
\hline$\left[\mathrm{CO}_{2}\right], \%$ & 0.0 & 2.0 & 1.5 & & 4.6 \\
\hline Timing of phase 2 & d 0 to 9 & d 1 to 9 & d 0 to 8 & d 0 to 9 & d 0 to 14 \\
\hline $\mathrm{D}_{\mathrm{LO}}, \mathrm{mmol} / \mathrm{kg}$ of $\mathrm{DM}$ per $\mathrm{d}$ & $12 \pm 2$ & $11 \pm 2$ & $15 \pm 2$ & $12 \pm 3$ & $10 \pm 1$ \\
\hline$\left[\mathrm{CO}_{2}\right], \%$ & 0.0 & 2.0 & 1.2 & 6.0 & 10.5 \\
\hline Timing of phase 3 & d 4 to 9 & d 5 to 9 & d 5 to 8 & d 5 to 9 & d 5 to 9 \\
\hline $\mathrm{C}_{\mathrm{LT}}, \mathrm{mmol} / \mathrm{kg}$ of $\mathrm{DM}$ per $\mathrm{d}$ & $106 \pm 7$ & $81 \pm 6$ & $104 \pm 11$ & $74 \pm 7$ & $61 \pm 7$ \\
\hline$\left[\mathrm{CO}_{2}\right], \%$ & 0.0 & 2.0 & 3.3 & 6.0 & 9.2 \\
\hline Timing of phase 4 & d 4 to 16 & d 3 to 12 & d 5 to 14 & d 5 to 16 & d 5 to 14 \\
\hline $\mathrm{D}_{\mathrm{LT}}, \mathrm{mmol} / \mathrm{kg}$ of $\mathrm{DM}$ per $\mathrm{d}$ & $32 \pm 2$ & $42 \pm 2$ & $38 \pm 6$ & $27 \pm 2$ & $20 \pm 3$ \\
\hline$\left[\mathrm{CO}_{2}\right], \%$ & 0.0 & 2.0 & 3.8 & 6.0 & 16.1 \\
\hline
\end{tabular}

${ }^{1}$ Values are the means of duplicate runs carried out under the same conditions; only a single run was carried out under NRA conditions.

${ }^{2}$ Parameters: $\mathrm{C}_{\mathrm{LO}}=$ lactose maximal consumption rate in rind; $\mathrm{D}_{\mathrm{LO}}=$ lactose maximal decreasing rate in the core; $\mathrm{C}_{\mathrm{LT}}=$ lactate consumption rate in the rind; $\mathrm{D}_{\mathrm{LT}}=$ lactate decreasing rate in the core; $\left[\mathrm{CO}_{2}\right]=\mathrm{CO}_{2}$ concentration; phase 1 = linear decreasing phase.

${ }^{3}$ Atmospheric conditions: CRA = continuously renewed atmosphere under which $\mathrm{CO}_{2}$ and $\mathrm{O}_{2}$ levels remained at 0 and $21 \%$, respectively; PRA = periodically renewed atmosphere under which the ripening chamber was sealed but each day, if necessary, the $\mathrm{CO}_{2}$ concentration was decreased to $2 \%$ by air injection $\left(\mathrm{O}_{2}\right.$ decreased to 17 to $\left.18 \%\right) ; \mathrm{NRA}=$ no renewed atmosphere under which the chamber was sealed during chamber ripening (accumulation of $\mathrm{CO}_{2}$ up to 20\%, disappearance of $\mathrm{O}_{2}$ ); $2 \mathrm{CO}_{2}=\mathrm{CO}_{2}$ concentration maintained at $2 \%$ from d 0 to 16 , with $\mathrm{O}_{2}$ close to 17 to $18 \%$; and $6 \mathrm{CO}_{2}=\mathrm{CO}_{2}$ concentration kept constant at $6 \%$ from d 0 to 16 , with $\mathrm{O}_{2} \sim 12$ to $13 \%$. 
Table 4. Values of kinetic descriptors of nitrogen concentration dynamics in relation to atmospheric conditions during chamber ripening (from d 0 to 16 ) of a Camembert-type cheese ${ }^{1}$

\begin{tabular}{|c|c|c|c|c|c|}
\hline Parameter & \multicolumn{5}{|c|}{ Atmospheric conditions ${ }^{2}$} \\
\hline \multicolumn{6}{|l|}{ Acid-soluble N (ASN) } \\
\hline Timing & d 3 to 6 & d 4 to 6 & d 4 to 6 & d 4 to 6 & d 4 to 7 \\
\hline$V_{\max }( \pm S D), g / 100 \mathrm{~g}$ of total $\mathrm{N}$ per $\mathrm{d}$ & $26 \pm 2$ & $43 \pm 3$ & $38 \pm 3$ & $33 \pm 3$ & $27 \pm 3$ \\
\hline$\left[\mathrm{CO}_{2}\right], \%$ & 0.0 & 2.0 & 3.3 & 6.0 & 7.1 \\
\hline $\mathrm{d}$ for $\mathrm{ASN}=100 \%$ & 7 & 6 & 8 & 7 & 8 \\
\hline Initial NPN & $6 \pm 3$ & $6 \pm 2$ & $4 \pm 1$ & $6 \pm 2$ & $4 \pm 1$ \\
\hline Timing & d 4 to 7 & d 4 to 8 & d 4 to 13 & d 4 to 15 & d 4 to 15 \\
\hline$V_{\max }( \pm S D), g / 100 \mathrm{~g}$ of total $\mathrm{N}$ per $\mathrm{d}$ & $16 \pm 2$ & $11 \pm 1$ & $3.1 \pm 0.4$ & $2.6 \pm 0.3$ & $2.3 \pm 0.3$ \\
\hline$\left[\mathrm{CO}_{2}\right], \%$ & 0.0 & 2.0 & 3.4 & 6.0 & 6.1 \\
\hline$[\mathrm{NPN}]_{\max }$ & $50 \pm 6$ & $46 \pm 4$ & $37 \pm 3$ & $43 \pm 4$ & $49 \pm 1$ \\
\hline $\mathrm{d}$ for $[\mathrm{NPN}]_{\max }$ & 6 & 7 & 13 & 19 & 18 \\
\hline $\mathrm{R}$ & 0.96 & 0.97 & 0.82 & 0.82 & 0.91 \\
\hline \multicolumn{6}{|l|}{ Free ammonium $\left(\mathrm{NH}_{4}^{+}\right)$} \\
\hline$\Delta\left[\mathrm{NH}_{4}^{+}\right]_{\max }, \mathrm{g}$ of $\mathrm{NH}_{3} / \mathrm{kg}$ of $\mathrm{DM}$ & 12.0 & 6.3 & 10.4 & 9.6 & 8.2 \\
\hline $\mathrm{R}$ & 0.92 & 0.99 & 0.97 & 0.90 & 0.97 \\
\hline
\end{tabular}

${ }^{1}$ Values are the means of duplicate runs carried out under the same conditions; only a single run was carried out under NRA conditions.

${ }^{2}$ Atmospheric conditions: CRA = continuously renewed atmosphere under which $\mathrm{CO}_{2}$ and $\mathrm{O}_{2}$ levels remained at 0 and $21 \%$, respectively; PRA = periodically renewed atmosphere under which the ripening chamber was sealed but each day, if necessary, the $\mathrm{CO}_{2}$ concentration was decreased to $2 \%$ by air injection $\left(\mathrm{O}_{2}\right.$ decreased to 17 to $\left.18 \%\right)$; NRA = no renewed atmosphere under which the chamber was sealed during chamber ripening (accumulation of $\mathrm{CO}_{2}$ up to $20 \%$, disappearance of $\mathrm{O}_{2}$ ) $; 2 \mathrm{CO}_{2}=\mathrm{CO}_{2}$ concentration maintained at $2 \%$ from d 0 to 16, with $\mathrm{O}_{2}$ close to 17 to $18 \%$; and $6 \mathrm{CO}_{2}=\mathrm{CO}_{2}$ concentration kept constant at $6 \%$ from d 0 to 16 , with $\mathrm{O}_{2} \sim 12$ to $13 \%$.

not shown). Under all conditions except NRA, bacterial concentration showed a lag phase from d 0 to 9 . After this lag phase, and until d $16\left(6 \mathrm{CO}_{2}\right), \mathrm{d} 20$ (CRA, PRA) or d $33\left(2 \mathrm{CO}_{2}\right), B$. aurantiacum grew with a maximal growth rate $\left(\mu_{\max }\right)$ depending on the $\mathrm{CO}_{2}$ concentration during chamber ripening (Table 1 ). In the absence of $\mathrm{CO}_{2}$ (CRA), $\mu_{\max }$ was the highest $\left(0.46 \pm 0.07 \mathrm{~d}^{-1}\right)-35 \%$ higher than that obtained when the $\mathrm{CO}_{2}$ concentration was under 2 or $6 \%$. After this growth phase, $B$. aurantiacum concentration remained constant, but its value depended on the $\mathrm{CO}_{2}$ level. When $\mathrm{CO}_{2}$ levels were less than $6 \%, \mathrm{X}_{\max }$ was between $3 \times 10^{8}$ and $10 \times 10^{8} \mathrm{cfu} / \mathrm{g}$. When $\mathrm{CO}_{2}$ levels were $6.0 \%\left(6 \mathrm{CO}_{2}\right), \mathrm{X}_{\max }$ was divided by about 300 in relation to $2 \mathrm{CO}_{2}$ and CRA. Under NRA (the highest $\mathrm{CO}_{2}$ level), B. aurantiacum did not grow, and its concentration remained constant, about $4 \times 10^{4}$ $\mathrm{cfu} / \mathrm{g}$ during chamber ripening. After d 16 and until 40 , no bacteria were found in the rind. The ANOVA confirmed that the highest $\mathrm{CO}_{2}$ concentrations present in the ripening chamber significantly inhibited $B$. aurantiacum growth (data not shown).

\section{Biochemical Changes in Ripening Cheeses in Relation to Atmospheric Conditions}

Table 2 shows the descriptors of cheese rind $\mathrm{pH}\left(\mathrm{V}_{\max }\right.$ and $\mathrm{pH}_{\mathrm{max}}$ in relation to $\mathrm{CO}_{2}$ concentration. Regardless of the $\mathrm{CO}_{2}$ concentration used during chamber ripening, no significant differences of $\mathrm{pH}$ descriptors were observed. The ANOVA confirmed that no significant differences existed between these dynamics (data not shown).

The atmospheric conditions of ripening $\left(\mathrm{CO}_{2}\right.$ level $)$ did not have a significant effect on lactose consumption rate in the rind $\left(\mathrm{C}_{\mathrm{LO}}\right.$, mean value $18 \pm 3 \mathrm{mmol} / \mathrm{kg}$ of $\mathrm{DM}$ per $\mathrm{d})$ and lactose disappearance in the core $\left(\mathrm{D}_{\mathrm{LO}}\right.$, mean value $=12 \pm 2 \mathrm{mmol} / \mathrm{kg}$ of DM per d) at $95 \%$ confidence level (Table 3). The ANOVA confirmed that there were no significant differences (data not shown).

Initial presence (d 0) of $\mathrm{CO}_{2}$ seemed to have slightly negative effect on lactate consumption by the microorganisms present on the surface $\left(\mathrm{C}_{\mathrm{LT}}\right)$, but it did not have any effect on lactate disappearance rate $\left(\mathrm{D}_{\mathrm{LT}}\right)$, consecutive to lactate consumption in the core by $G$. candidum and K. lactis (Leclercq-Perlat et al., 2004), as well as to its diffusion from the core to the rind. Indeed, $\mathrm{C}_{\mathrm{LT}}$ of CRA and PRA was higher than for the other conditions (Table 3). Under NRA (results not shown) lactate consumption in the rind and in the core was stopped on $d 10$ and 23, reaching about 97 and 10 $\mathrm{mmol} / \mathrm{kg}$ of DM, respectively. In the chamber, between d 10 and $16, \mathrm{CO}_{2}$ concentration was the highest: equal to $19.2 \%$ on d 10 and remaining constant at $20 \%$ from 

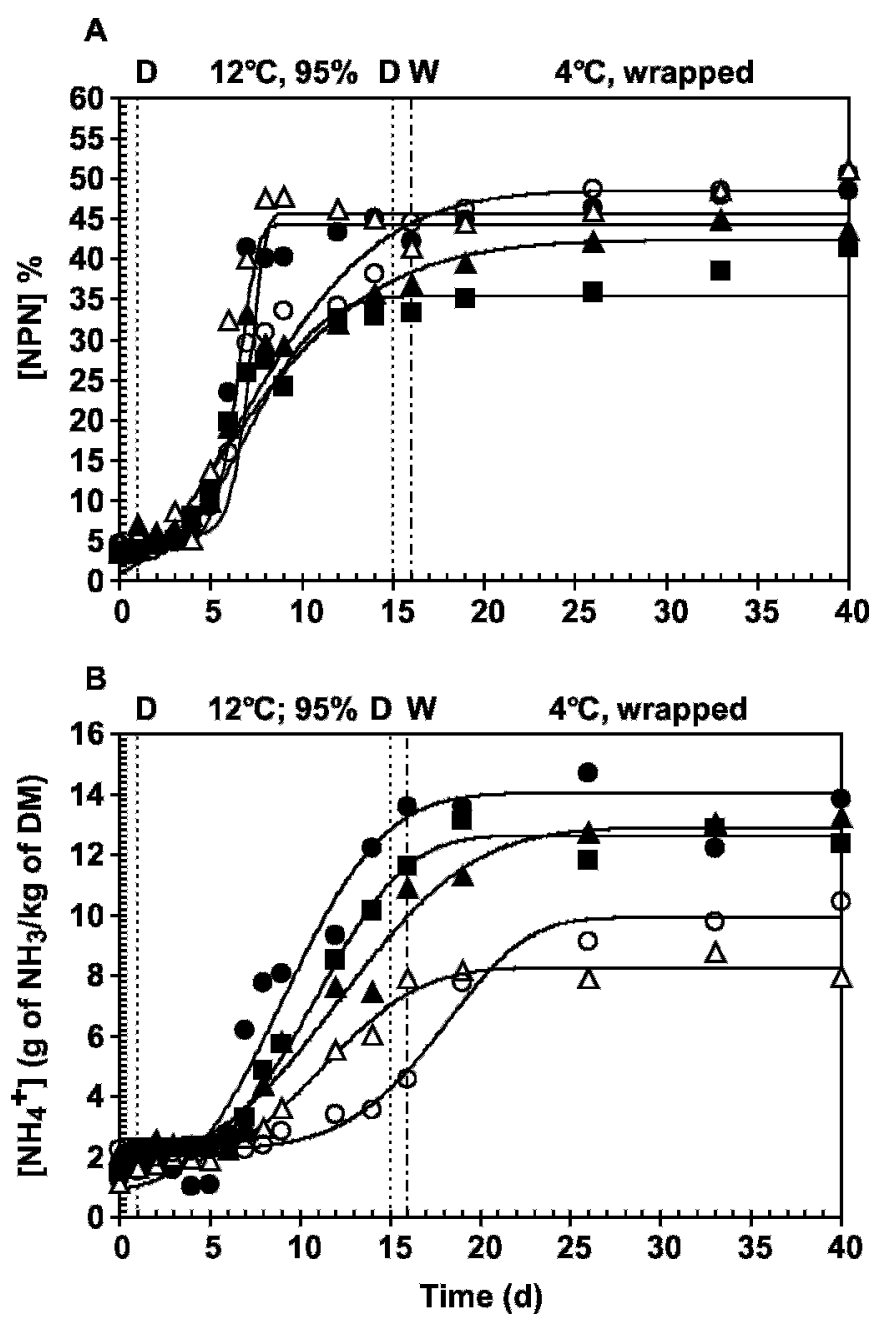

Figure 2. Changes in A) NPN indices and B) free $\mathrm{NH}_{4}^{+}$concentration in the rind in relation to ripening time (from d 0 to 40). Atmospheric conditions: CRA $(\bullet)=$ continuously renewed atmosphere under which $\mathrm{CO}_{2}$ and $\mathrm{O}_{2}$ levels remained at 0 and $21 \%$, respectively; PRA $(\square)=$ periodically renewed atmosphere under which the ripening chamber was sealed but each day, if necessary, the $\mathrm{CO}_{2}$ concentration was decreased to $2 \%$ by air injection $\left(\mathrm{O}_{2}\right.$ decreased to 17 to $\left.18 \%\right)$; NRA $(O)=$ no renewed atmosphere under which the chamber was sealed during chamber ripening (accumulation of $\mathrm{CO}_{2}$ up to $20 \%$, disappearance of $\left.\mathrm{O}_{2}\right) ; 2 \mathrm{CO}_{2}(\triangle)=\mathrm{CO}_{2}$ concentration maintained at $2 \%$ from d 0 to 16 , with $\mathrm{O}_{2}$ close to 17 to $18 \%$; and $6 \mathrm{CO}_{2}(\boldsymbol{\Delta})=\mathrm{CO}_{2}$ concentration kept constant at $6 \%$ from $\mathrm{d} 0$ to 16 , with $\mathrm{O}_{2} \sim 12$ to $13 \%$.

$\mathrm{d} 11$ to 16 . At these $\mathrm{CO}_{2}$ levels, all microorganism activities slowed down. Lactate diffusion from the core to the rind continued until d 23 and stopped when the 2 lactate concentrations were equal. This could explain why these lactate rates $\left(\mathrm{C}_{\mathrm{LT}}\right.$ and $\left.\mathrm{D}_{\mathrm{LT}}\right)$ obtained under NRA were lower than under the other atmospheric conditions. The ANOVA confirmed that the lactate dynamics in the rind were similar under $6 \mathrm{CO}_{2}, \mathrm{CRA}, 2 \mathrm{CO}_{2}$, and PRA. The dynamics in the rind and in the core were the lowest under NRA conditions (data not shown).
Regardless of the $\mathrm{CO}_{2}$ concentration used during chamber ripening, the kinetic increases occurred during the same ripening time (from d 3 or 4 to $d 6$ or 7). No significant difference of initial ASN concentration was observed (Table 4). The maximal rate $\left(\mathrm{V}_{\max }\right)$ was the highest for $2 \mathrm{CO}_{2}$ and PRA conditions (Table 4). The maximal rate was lowest when $\mathrm{CO}_{2}$ level was negligible (CRA) or the highest when $\mathrm{CO}_{2}$ level was maximal (NRA). Moreover, when $\mathrm{V}_{\max }$ was the highest, the time for which ASN level was $100 \%$ was the lowest $\left(2 \mathrm{CO}_{2}\right)$; indeed, it seemed that this proteolytic index became quickly maximal. However, ANOVA showed that there were no significant differences (data not shown).

When $\mathrm{CO}_{2}$ concentration was lower or equal to $2 \%$ $\left(\mathrm{CRA}, 2 \mathrm{CO}_{2}\right)$, the NPN rates $\left(\mathrm{V}_{\max }\right)$ (Figure $2 \mathrm{~A}$, Table 4) were between 4 and 5 times higher than those obtained for the other runs $\left(\mathrm{CO}_{2}\right.$ level $\left.\geq 3 \%\right)$, and the time for which NPN level was maximal was the lowest (d 6 to 7). No significant differences of the maximal NPN were found regardless of $\mathrm{CO}_{2}$ concentration in the chamber. Under $6 \mathrm{CO}_{2}$ and $\mathrm{NRA}$ (the highest $\mathrm{CO}_{2}$ level) conditions, the maximal concentration of NPN was obtained after wrapping, on d 19 and 18, respectively.

Analysis of variance (Table 7) confirmed that under PRA, the NPN dynamic was the lowest. The NPN dynamics of CRA (starting on d 9) were the same as for $2 \mathrm{CO}_{2}$ (starting on $\mathrm{d} 7$ ) but with a delay of $2 \mathrm{~d}$. Under $6 \mathrm{CO}_{2}$ and NRA conditions, there was a weak acceleration of NPN production, from d 19 and $d 16$ until d 40 , respectively.

For $\mathrm{NH}_{3}$ evolutions, 3 observations can be made (Figure 2B; Table 4). Firstly, no production of $\mathrm{NH}_{3}$ was observed before d 7. Secondly, except under NRA, $\mathrm{NH}_{3}$ production occurred during chamber ripening and finished with wrapping (d 16). Under $\mathrm{NRA}, \mathrm{NH}_{3}$ increase occurred from d 12 until $8 \mathrm{~d}$ after wrapping. Thirdly, an initial presence of $\mathrm{CO}_{2}$ or an important concentration of $\mathrm{CO}_{2}$ induced lower production of $\mathrm{NH}_{3}$.

Whatever the atmospheric conditions, the ANOVA study detected no significant effect from d 0 to 6 (Table 7B). Under NRA, regardless of day, the $\mathrm{NH}_{3}$ concentration was the lowest. From d 6 until 40, CRA and PRA runs presented the fastest dynamics and the highest values of $\mathrm{NH}_{3}$ concentrations. Under $2 \mathrm{CO}_{2}$ or $6 \mathrm{CO}_{2}$, ammonium concentration dynamics formed an intermediate group.

\section{Influence of Atmospheric Composition on Cheese Appearance}

Figure 3 shows the progression of underrind thickness in relation to ripening time (from d 0 to 40 ) and to atmospheric conditions used during chamber ripening. Table 5 presents the duration of lag period $\left(\mathrm{T}_{\mathrm{UR}}=0 \mathrm{~mm}\right)$ 
Table 5. Values of kinetic descriptors of underrind thickness $\left(\mathrm{T}_{\mathrm{UR}}, \mathrm{mm}\right)$ in relation to atmospheric conditions during chamber ripening (from d 0 to 16) of a Camembert-type cheese ${ }^{1}$

\begin{tabular}{|c|c|c|c|c|c|}
\hline \multirow[b]{2}{*}{ Parameters $^{2}$} & \multicolumn{5}{|c|}{ Atmospheric conditions ${ }^{3}$} \\
\hline & CRA & $2 \mathrm{CO}_{2}$ & PRA & $6 \mathrm{CO}_{2}$ & NRA \\
\hline $\mathrm{d}$ for $\mathrm{T}_{\mathrm{UR}}=0$ & $\mathrm{~d} 0$ to 5 & d 0 to 7 & d 0 to 6 & d 0 to 8 & d 0 to 8 \\
\hline Timing & d 14 to 40 & d 6 to 26 & d 14 to 40 & d 6 to 26 & d 14 to 40 \\
\hline $\mathrm{V}_{\max }$ & $0.63 \pm 0.09$ & $0.63 \pm 0.09$ & $0.60 \pm 0.08$ & $0.7 \pm 0.1$ & $0.65 \pm 0.08$ \\
\hline Time to reach $V_{\max }$, $d$ & $27 \pm 1$ & $14 \pm 1$ & $30 \pm 2$ & $16 \pm 2$ & $32 \pm 2$ \\
\hline Type of ripening & Slow-fast & Fast-slow & Slow-fast & Fast-slow & Slow-fast \\
\hline $\mathrm{R}$ & 0.992 & 0.997 & 0.996 & 0.995 & 0.998 \\
\hline
\end{tabular}

${ }^{1}$ Values are the means of 2 runs carried out under the same conditions; only a single run was carried out under NRA conditions.

${ }^{2}$ Parameters: $\mathrm{V}_{\max }=$ maximal rate of increase.

${ }^{3}$ Atmospheric conditions: CRA = continuously renewed atmosphere under which $\mathrm{CO}_{2}$ and $\mathrm{O}_{2}$ levels remained at 0 and $21 \%$, respectively; PRA = periodically renewed atmosphere under which the ripening chamber was sealed but each day, if necessary, the $\mathrm{CO}_{2}$ concentration was decreased to $2 \%$ by air injection $\left(\mathrm{O}_{2}\right.$ decreased to 17 to $\left.18 \%\right) ; \mathrm{NRA}=$ no renewed atmosphere under which the chamber was sealed during chamber ripening (accumulation of $\mathrm{CO}_{2}$ up to $20 \%$, disappearance of $\mathrm{O}_{2}$ ); $2 \mathrm{CO}_{2}=\mathrm{CO}_{2}$ concentration maintained at $2 \%$ from d 0 to 16 , with $\mathrm{O}_{2}$ close to 17 to $18 \%$; and $6 \mathrm{CO}_{2}=\mathrm{CO}_{2}$ concentration kept constant at $6 \%$ from d 0 to 16 , with $\mathrm{O}_{2} \sim 12$ to $13 \%$.

and fast increase phase as well as its kinetic descriptors $\left(\mathrm{V}_{\max }\right.$, time for $\left.\mathrm{V}_{\max }\right)$ and the type of ripening.

Two different ripening progressions were observed (Figure 3). In the presence of $\mathrm{CO}_{2}$ on $\mathrm{d} 0\left(2 \mathrm{CO}_{2}\right.$ and $6 \mathrm{CO}_{2}$ ), the underrind thickness increased greatly be-

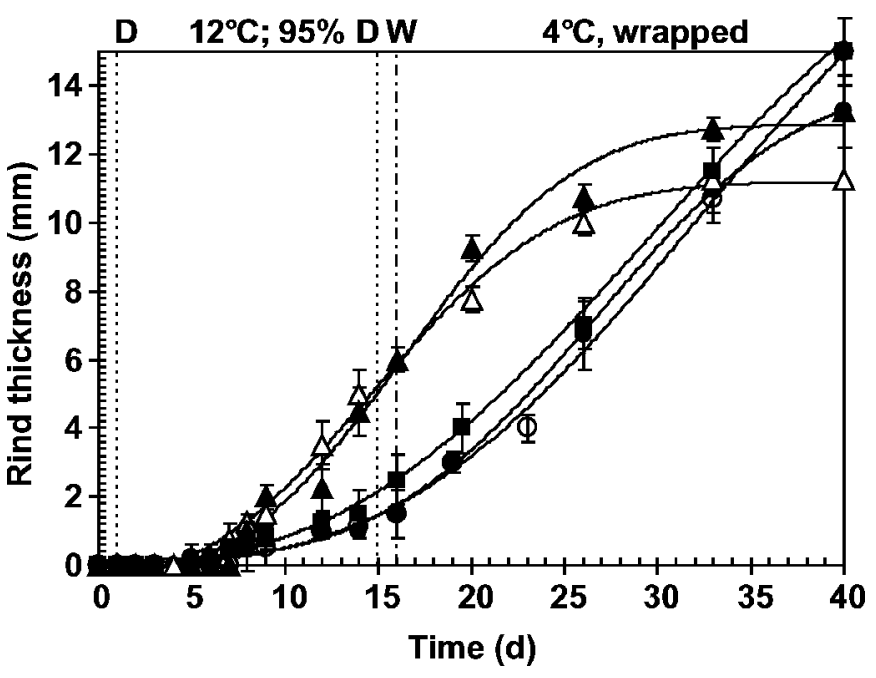

Figure 3. Changes in creamy underrind thickness $(\mathrm{mm})$ throughout the entire ripening process (from d 0 to 40). All the underrind thickness progressions were made using Weibull modeling. $\mathrm{D}=$ surface drying period; $\mathrm{W}=$ wrapping on $\mathrm{d} 16$. Atmospheric conditions: CRA $(\bullet)=$ continuously renewed atmosphere under which $\mathrm{CO}_{2}$ and $\mathrm{O}_{2}$ levels remained at 0 and $21 \%$, respectively; PRA $(\square)=$ periodically renewed atmosphere under which the ripening chamber was sealed but each day, if necessary, the $\mathrm{CO}_{2}$ concentration was decreased to $2 \%$ by air injection $\left(\mathrm{O}_{2}\right.$ decreased to 17 to $\left.18 \%\right)$; $\mathrm{NRA}(\mathrm{O})=$ no renewed atmosphere under which the chamber was sealed during chamber ripening (accumulation of $\mathrm{CO}_{2}$ up to $20 \%$, disappearance of $\mathrm{O}_{2}$ ); $2 \mathrm{CO}_{2}$ $(\triangle)=\mathrm{CO}_{2}$ concentration maintained at $2 \%$ from d 0 to 16 , with $\mathrm{O}_{2}$ close to 17 to $18 \%$; and $6 \mathrm{CO}_{2}(\mathbf{\Delta})=\mathrm{CO}_{2}$ concentration kept constant at $6 \%$ from d 0 to 16 , with $\mathrm{O}_{2} \sim 12$ to $13 \%$. tween $\mathrm{d} 6$ and 26. After this phase, the underrind thickness remained constant, reaching about half the thickness of the cheeses on $d 34$. The ripening of these 2 tests was termed fast-slow. For the runs free of $\mathrm{CO}_{2}$ on d 0 (CRA, PRA, and NRA), the underrind thickness increased at a low rate from d 6 to 16. After that, and until d 40, it increased quickly, reaching half the thickness of the cheeses on $d 40$; this ripening was termed slow-fast. The $\mathrm{CO}_{2}$ concentration of atmospheric composition in the chamber did not have a significant effect on $\mathrm{V}_{\max }$ (Table 5) but it did have a significant effect on time associated with $V_{\max }$, as can be seen by the shape of the curves (Figure 3).

When $\mathrm{CO}_{2}$ concentration was higher than $6 \%$ during the ripening period ( $\mathrm{PRA}, 6 \mathrm{CO}_{2}, \mathrm{NRA}$ ) the underrind was too runny. The higher the $\mathrm{CO}_{2}$ concentration and the longer the time in ripening, the poorer the underrind quality.

Regardless of $\mathrm{CO}_{2}$ concentration, $P$. camemberti mycelium began to grow on the same day (d 5). However, when growth started, appearance of cheese surface, color, and density of mycelium as well as microorganism growth depended on $\mathrm{CO}_{2}$ level. When $\mathrm{CO}_{2}$ concentration was 0 or $2 \%$, the appearance of the cheese surface corresponded to the 3 targeted visual criteria (white or light cream color, density of mycelium, and the uniformity of these 2 criteria). Increases in $\mathrm{CO}_{2}$ concentration above $2 \%$ resulted in worse cheese surface appearance.

On d 12, under NRA conditions, the cheese color was gray with some brown spots not significantly distributed; the cheese edges were also brown. The aerial mycelia of $P$. camembert $i$ were no longer observed in the middle of the surface. Concerning color and appearance, the cheese surface was similar to G. candidum biofilms 
Table 6. Analysis of variance ${ }^{1}$ of Geotrichum candidum and Penicillium camemberti concentrations throughout the entire ripening process (from $\mathrm{d} 0$ to 40 ) in cheeses ripened using different $\mathrm{CO}_{2}$ concentrations during the chamber ripening phase (from d 0 to 16$)^{2}$

\begin{tabular}{|c|c|c|c|c|c|}
\hline \multirow{2}{*}{$\begin{array}{l}\text { Ripening } \\
\text { time (d) }\end{array}$} & \multicolumn{5}{|c|}{ Atmospheric conditions ${ }^{3}$} \\
\hline & CRA & $2 \mathrm{CO}_{2}$ & PRA & $6 \mathrm{CO}_{2}$ & NRA \\
\hline \multicolumn{6}{|c|}{ G. candidum } \\
\hline 0 & $*$ & $*$ & * & $*$ & * \\
\hline 1 & $*$ & $*$ & * & $*$ & $*$ \\
\hline 2 & $*$ & $* * *$ & $* *$ & $*$ & $*$ \\
\hline 3 & * & $* * * *$ & $* * *$ & $* *$ & $* * *$ \\
\hline 5 & $*$ & $* * *$ & $* *$ & $* *$ & $* *$ \\
\hline 6 & $*$ & $* * *$ & $* * *$ & $* *$ & $* * *$ \\
\hline 7 & $*$ & $* *$ & $* *$ & $* *$ & $* *$ \\
\hline 8 & $*$ & $* *$ & $* *$ & $* * *$ & $* * *$ \\
\hline 9 & $*$ & $* *$ & $* *$ & $* * *$ & $* * *$ \\
\hline 12 & * & $* *$ & $* *$ & $* * *$ & $* * *$ \\
\hline 14 & * & $* *$ & $* *$ & $* * *$ & $* *$ \\
\hline 16 & $*$ & $* *$ & $* *$ & $* * * *$ & $* * *$ \\
\hline 19 & $*$ & $* *$ & $* *$ & $* * *$ & $* * *$ \\
\hline 26 & $*$ & $*$ & $* *$ & $* * *$ & $* *$ \\
\hline 33 & $*$ & $*$ & $* *$ & $* * *$ & $* *$ \\
\hline 40 & $*$ & $*$ & * & $* * *$ & $* *$ \\
\hline \multicolumn{6}{|c|}{ P. camemberti } \\
\hline 0 & $*$ & $*$ & * & $*$ & $*$ \\
\hline 1 & $*$ & $*$ & * & $*$ & $*$ \\
\hline 2 & $*$ & $*$ & * & * & * \\
\hline 3 & $*$ & $* *$ & * & $*$ & * \\
\hline 5 & * & ** & * & * & $*$ \\
\hline 6 & $*$ & $* *$ & * & $*$ & $*$ \\
\hline 7 & $* *$ & $* * * *$ & $* * *$ & $* *$ & $*$ \\
\hline 8 & $* *$ & $* * *$ & $* *$ & $*$ & $*$ \\
\hline 9 & $*$ & $* * *$ & $* *$ & * & * \\
\hline 12 & $*$ & $* *$ & $* *$ & * & $* *$ \\
\hline 14 & $*$ & $* *$ & $*$ & $*$ & $* *$ \\
\hline 16 & * & $*$ & * & * & $*$ \\
\hline 19 & $*$ & $*$ & * & $*$ & $*$ \\
\hline 26 & * & $*$ & * & * & $*$ \\
\hline 33 & $*$ & $*$ & * & $*$ & $*$ \\
\hline 40 & $*$ & $*$ & * & * & * \\
\hline
\end{tabular}

${ }^{1}$ Newman-Keuls test with $P$-value of 0.01 .

${ }^{2}$ Data represent $\log _{10}$ of the concentrations of viable $G$. candidum and $P$. camemberti. On each day, data with the same score are not significantly different. $*$ = statistical group with the lowest values; $* *$ and $* * *=$ statistical groups with intermediate values; $* * * *=$ statistical group with the highest values.

${ }^{3}$ Atmospheric conditions: CRA = continuously renewed atmosphere under which $\mathrm{CO}_{2}$ and $\mathrm{O}_{2}$ levels remained at 0 and $21 \%$, respectively; PRA = periodically renewed atmosphere under which the ripening chamber was sealed but each day, if necessary, the $\mathrm{CO}_{2}$ concentration was decreased to $2 \%$ by air injection $\left(\mathrm{O}_{2}\right.$ decreased to 17 to $\left.18 \%\right)$; $\mathrm{NRA}=$ no renewed atmosphere under which the chamber was sealed during chamber ripening (accumulation of $\mathrm{CO}_{2}$ up to $20 \%$, disappearance of $\left.\mathrm{O}_{2}\right) ; 2 \mathrm{CO}_{2}=\mathrm{CO}_{2}$ concentration maintained at $2 \%$ from d 0 to 16 , with $\mathrm{O}_{2}$ close to 17 to $18 \%$; and $6 \mathrm{CO}_{2}=\mathrm{CO}_{2}$ concentration kept constant at $6 \%$ from d 0 to 16 , with $\mathrm{O}_{2} \sim 12$ to $13 \%$.

found on cheese ripened by this yeast. Moreover, the cheese completely lost its shape: the rind collapsed all around the core such that the cheese acquired a bowlerhat shape; wrapping did not change the shape. Under $6 \mathrm{CO}_{2}$ and PRA conditions, the cheese color was white and gray and the central core collapsed completely. Moreover, the $\mathrm{CO}_{2}$ level present in the chamber de-
Table 7. Analysis of variance ${ }^{1}$ of NPN index and change in free ammonium $\left(\mathrm{NH}_{3}\right)$ concentration throughout the entire ripening process (from $\mathrm{d} 0$ to 40 ) in cheeses ripened using different $\mathrm{CO}_{2}$ concentrations during the chamber ripening phase (from $\mathrm{d} 0$ to 16$)^{2}$

\begin{tabular}{|c|c|c|c|c|c|}
\hline \multirow{2}{*}{$\begin{array}{l}\text { Ripening } \\
\text { time (d) }\end{array}$} & \multicolumn{5}{|c|}{ Atmospheric conditions ${ }^{3}$} \\
\hline & CRA & $2 \mathrm{CO}_{2}$ & PRA & $6 \mathrm{CO}_{2}$ & NRA \\
\hline NPN index & $*$ & $*$ & * & $*$ & $*$ \\
\hline 0 & * & $*$ & $*$ & * & $*$ \\
\hline 1 & * & $*$ & $*$ & * & $*$ \\
\hline 2 & $*$ & $*$ & $*$ & * & $*$ \\
\hline 3 & * & * & $*$ & * & $*$ \\
\hline 5 & * & $*$ & $*$ & * & $*$ \\
\hline 6 & * & $*$ & $*$ & * & $*$ \\
\hline 7 & $*$ & $* *$ & $*$ & * & $*$ \\
\hline 8 & $*$ & $* *$ & $*$ & * & $*$ \\
\hline 9 & $* *$ & $* *$ & $*$ & * & $*$ \\
\hline 12 & $* *$ & $* *$ & $*$ & $*$ & $*$ \\
\hline 14 & $* *$ & $* *$ & $*$ & $*$ & $*$ \\
\hline 16 & $* *$ & $* *$ & $*$ & $*$ & $* *$ \\
\hline 19 & $* * *$ & $* * *$ & $*$ & $* *$ & $* * *$ \\
\hline 26 & $* *$ & $* *$ & $*$ & $* *$ & $* *$ \\
\hline 33 & $* *$ & $* *$ & $*$ & $* *$ & $* *$ \\
\hline 40 & $* *$ & $* *$ & $*$ & $*$ & $* *$ \\
\hline \multicolumn{6}{|l|}{$\Delta\left[\mathrm{NH}_{3}\right]^{4}$} \\
\hline 0 & * & * & $*$ & * & * \\
\hline 1 & * & $*$ & * & * & $*$ \\
\hline 2 & * & $*$ & $*$ & * & $*$ \\
\hline 3 & $*$ & $*$ & $*$ & * & $*$ \\
\hline 5 & $*$ & $*$ & $*$ & * & $*$ \\
\hline 6 & $*$ & $*$ & $*$ & * & $*$ \\
\hline 7 & $* * *$ & $* *$ & $* *$ & * & $*$ \\
\hline 8 & $* * * *$ & $* *$ & $* * *$ & $* *$ & $*$ \\
\hline 9 & $* * * * *$ & $* *$ & $* * * *$ & $* * *$ & $*$ \\
\hline 12 & $* * * *$ & $* *$ & $* * *$ & $* *$ & $*$ \\
\hline 14 & $* * * *$ & $* *$ & $* * *$ & $* *$ & $*$ \\
\hline 16 & $* * *$ & $* *$ & $* * *$ & $* *$ & $*$ \\
\hline 19 & $* * *$ & $*$ & $* * *$ & $* *$ & $*$ \\
\hline 26 & $* * *$ & $*$ & $* *$ & $* *$ & $*$ \\
\hline 33 & $* *$ & $*$ & $* *$ & $* *$ & $*$ \\
\hline 40 & $* *$ & $*$ & $* *$ & $* *$ & $*$ \\
\hline
\end{tabular}

${ }^{1}$ Newman-Keuls test with $P$-value of 0.01 .

${ }^{2}$ Data represent $\log _{10}$ of the concentrations of viable $G$. candidum and $P$. camemberti. On each day, data with the same score are not significantly different. $*$ = statistical group with the lowest values; $* *, * * *$, and $* * * *=$ statistical groups with intermediate values; $* * * * *=$ statistical group with the highest values.

${ }^{3}$ Atmospheric conditions: CRA = continuously renewed atmosphere under which $\mathrm{CO}_{2}$ and $\mathrm{O}_{2}$ levels remained at 0 and $21 \%$, respectively; PRA = periodically renewed atmosphere under which the ripening chamber was sealed but each day, if necessary, the $\mathrm{CO}_{2}$ concentration was decreased to $2 \%$ by air injection $\left(\mathrm{O}_{2}\right.$ decreased to 17 to $\left.18 \%\right)$; $\mathrm{NRA}=$ no renewed atmosphere under which the chamber was sealed during chamber ripening (accumulation of $\mathrm{CO}_{2}$ up to $20 \%$, disappearance of $\left.\mathrm{O}_{2}\right) ; 2 \mathrm{CO}_{2}=\mathrm{CO}_{2}$ concentration maintained at $2 \%$ from d 0 to 16 , with $\mathrm{O}_{2}$ close to 17 to $18 \%$; and $6 \mathrm{CO}_{2}=\mathrm{CO}_{2}$ concentration kept constant at $6 \%$ from d 0 to 16 , with $\mathrm{O}_{2} \sim 12$ to $13 \%$.

${ }^{4} \mathrm{On}$ each riepning day, $\Delta\left[\mathrm{NH}_{3}\right]$ was equal to $\left[\mathrm{NH}_{3}\right]$ obtained on that d minus its initial (d 0 ) value.

graded the shape. The rind center was more or less collapsed, and the experts characterized this underrind as runny.

\section{DISCUSSION}

It is thought that the role of $K$. lactis and B. aurantiacum in $\mathrm{CO}_{2}$ production is negligible. In our case, what- 
ever the atmospheric conditions, $\mathrm{CO}_{2}$ production was insignificant during $K$. lactis growth. It was likewise for B. aurantiacum, and no significant $\mathrm{CO}_{2}$ production has been reported in the literature. For the runs without $\mathrm{CO}_{2}$ control (NRA, PRA), $\mathrm{CO}_{2}$ production was concomitant to $P$. camemberti mycelium growth (d 5 to 6 ). Adour et al. (2002) have shown that $P$. camemberti and G. candidum produced higher amounts of $\mathrm{CO}_{2}$. In our case, whatever the $\mathrm{CO}_{2}$ levels in the presence of an important $\mathrm{O}_{2}$ concentration ( $>12$ to $\left.13 \%\right)$, K. lactis grew in a similar manner and its specific growth rate $\left(\mu_{\max }\right)$ as well as its maximal concentration $\left(\mathrm{X}_{\max }\right)$ did not significantly differ regardless of atmospheric conditions. This could be due to $\mathrm{CO}_{2}$ or $\mathrm{O}_{2}$ levels in the chamber during the growth phase. Except under NRA, K. lactis death phase occurred after wrapping. This could be explained by an osmotic shock due to the reoxygenation of cheese during the wrapping as shown by Skjerdal et al. (1995) for some ripening bacteria. Under NRA, the death period of $K$. lactis took place during chamber ripening (d 10 to 16$)$ at the highest rate $(<10 \%)$. This could be explained by both an important $\mathrm{CO}_{2}$ quantity in the chamber after $\mathrm{d} 8(\geq 20 \%)$ and low levels of $\mathrm{O}_{2}$ $(\leq 1 \%)$ in the chamber, which induced lysis of $K$. lactis cells. In fact, $K$. lactis growth was not sensitive to $\mathrm{CO}_{2}$ and $\mathrm{O}_{2}$ concentrations. However, its death (period and rate) was related to atmospheric conditions $\left(\mathrm{CO}_{2}\right.$ and $\mathrm{O}_{2}$ ).

In absence of $\mathrm{CO}_{2}, G$. candidum dynamics were the lowest and, in presence of $6 \%$ of $\mathrm{CO}_{2}$, they appeared maximal (Table 6). These results were in accordance with those of Wells and Spalding (1975). Indeed, those authors have shown that G. candidum is able to grow under microaerophilic conditions and under elevated $\mathrm{CO}_{2}$ levels, and that it is stimulated by low $\mathrm{O}_{2}$ and high $\mathrm{CO}_{2}$ atmospheres. Moreover, Couriol et al. (2001) have shown that $\mathrm{CO}_{2}$ production was associated with $G$. candidum growth whereas Adour et al. (2002) have considered that G. candidum produced lower $\mathrm{CO}_{2}$ levels than $P$. camemberti mycelia in liquid media and pure cultivation.

Sporulation of $P$. camemberti was also increased by significant $\mathrm{CO}_{2}$ concentration in the chamber $(>6 \%)$. The specific rate $\left(\mu_{\max }\right)$ was maximal for a $\mathrm{CO}_{2}$ level close to $2 \%\left(2 \mathrm{CO}_{2}\right)$, whereas the maximal spore concentration $\left(\mathrm{X}_{\max }\right)$ was slightly higher under $6 \mathrm{CO}_{2}$ or NRA (Figure 1B). Using ANOVA, $P$. camemberti spore dynamics appeared maximal under $2 \mathrm{CO}_{2}$ and PRA (Table 6 ). These results are in accordance with those of Roger et al. (1998). Roger et al. (1998) have shown that a $\mathrm{CO}_{2}$ concentration of about $4 \%$ allowed for the best development of $P$. camemberti mycelia on Brie cheeses, but only if the $\mathrm{O}_{2}$ level was $>16 \%$. Similarly, Magan and Lacey (1984) have shown that $\mathrm{CO}_{2}$ concentrations close to $5 \%$ with low $\mathrm{O}_{2}$ concentrations stimulate growth of some Penicillium species on wheat extract medium if water activity and temperature are correctly chosen. Adour et al. (2002) have also shown that under their study conditions (liquid media, pure culture), $\mathrm{CO}_{2}$ promoted G. candidum growth (Table 1) but disadvantaged $P$. camemberti mycelium development. The poor development of $P$. camemberti visually observed for $\mathrm{CO}_{2}$ higher than $3 \%$ could also be explained as proposed by van den Tempel and Nielsen (2000). These authors have shown that 1) G. candidum was adapted to growth at low levels of oxygen and high levels of $\mathrm{CO}_{2}$; and 2) growth and sporulation of Penicillium roqueforti was negatively affected in the presence of $G$. candidum at high $\mathrm{CO}_{2}$ levels, irrespective of $\mathrm{O}_{2}$ levels. Although van den Tempel and Nielsen (2000) used $P$. roqueforti, the effects of $\mathrm{CO}_{2}$ and $\mathrm{O}_{2}$ could be similar or more important due to the higher sensitivity of $P$. camemberti to $\mathrm{O}_{2}$ (Doyon et al., 1997; Roger et al., 1998). The development of $P$. camemberti (mycelia as well as sporulation) in the presence of $G$. candidum was related to the $\mathrm{CO}_{2}$ level in chamber ripening. In fact, $\mathrm{CO}_{2}$ changed the equilibrium existing between these 2 strains. Indeed, the higher the $\mathrm{CO}_{2}$ concentration, the more significant the G. candidum concentration was in the stationary phase $\left(\mathrm{X}_{\max }\right)$ and the worse $P$. camemberti mycelium development (visual appearance) was.

In the absence of $\mathrm{CO}_{2}$ (CRA), exponential B. aurantiacum growth occurred on d 9 and continued after wrapping. The $\mathrm{pH}$ of the rind was favorable for $B$. aurantiacum but, surprisingly, its growth occurred $3 \mathrm{~d}$ after the rind $\mathrm{pH}$ reached its maximum (d 6), whereas in our previous study (Leclercq-Perlat et al., 2004), we have shown that growth of this species started as soon as $\mathrm{pH}$ of the rind reached neutral $\mathrm{pH}$. Its maximal growth rate was obtained in absence of $\mathrm{CO}_{2}$ (Table 1 ). However, maximal concentration $\left(\mathrm{X}_{\max }\right)$ was the same if the $\mathrm{O}_{2}$ level in the chamber was higher than $16 \%\left(\mathrm{CRA}, 2 \mathrm{CO}_{2}\right.$, PRA). In the other runs $\left(6 \mathrm{CO}_{2}, \mathrm{NRA}\right)$, its growth $\left(\mathrm{X}_{\max }\right)$ was negligible. Lower levels of $\mathrm{O}_{2}(<12$ to $13 \%)$ with high $\mathrm{CO}_{2}$ concentration had significant inhibitor effects on $B$. aurantiacum evolution; $B$. aurantiacum is considered a strict aerobic strain, and no growth occurs in absence of $\mathrm{O}_{2}$ (Rattray and Fox, 1999).

No significant effect on carbon substrate dynamics of $\mathrm{CO}_{2}$ levels during chamber ripening was observed on the cheese rind or in the cheese core, except under NRA. Indeed, $\mathrm{O}_{2}$ concentration was high $(\geq 11$ to $18 \%)$ and did not limit glycolysis. However, under NRA, the lactate consumption was stopped on d 11 when $\mathrm{CO}_{2}$ was $20 \%$ and $\mathrm{O}_{2}$ was negligible. The absence of $\mathrm{O}_{2}$ explains the limitation of these oxidative metabolisms as observed here. 
The $\mathrm{CO}_{2}$ level present in the chamber seemed to have no significant effects on ASN dynamics, but a slight effect of $\mathrm{CO}_{2}$ on $\mathrm{ASN}$ maximal rates was observed. However, it had a significant effect on NPN maximal rates (Table 7). Indeed, the $\mathrm{V}_{\max }$ values of NPN kinetics were the highest when $\mathrm{CO}_{2}$ concentration was the lowest ( 0 to $2 \%$ for CRA and $2 \mathrm{CO}_{2}$ ), and the time NPN concentration took to become maximal was the shortest (6 to $7 \mathrm{~d}$ ). However, the final NPN concentration (measured to $\mathrm{NPN}_{\max }$ ) was not significantly different. According to Sousa and et al. (2001), P. camemberti is the main agent of amino acid release in Camembert cheeses. This suggests that high $\mathrm{CO}_{2}(>2 \%)$ could have an inhibitor action on peptidasic activities during ripening.

Under CRA, the quantities of ammonium obtained in the rind were much higher than those found by Leclercq-Perlat et al. (2004). However, they were in accordance with those obtained by von Mrowetz (1979), who studied ammonium contents during Camembert cheese ripening without reporting cheese-making and ripening conditions. The following sequence of events could explain these significant differences. When a saturated salt $\left(\mathrm{KNO}_{3}\right)$ system was used to regulate $\mathrm{RH}$, a part of $\mathrm{KNO}_{3}$ was vaporized into the atmosphere, and by consequence, was deposited in the rind. This salt absorption induced a significant decrease of water activity in the rind (Gobbetti et al., 1999). These authors have also shown that a decrease of water activity involved a negative effect on the peptidase activity of some lactic acid bacterium strains. This negative effect on proteolysis could be verified for the other strains. Under CRA and PRA, ammonium production was higher and their dynamics were the fastest compared with those of the other atmospheric conditions. Similar to NPN dynamics, this could be due to an inhibition of aminopeptidase and deaminase enzymes by $\mathrm{CO}_{2}$. Indeed, according to Hemme et al. (1982), deaminases (aminooxidases or oxidoreductases) convert amino acids (or their amines) into $\mathrm{NH}_{3}$ and cetonic acids or aldehydes, which requires $\mathrm{O}_{2}$. Many ripening microorganisms, in particular, surface bacteria, are considered to be the most active in proteolysis. Rattray and Fox (1999) have reviewed the proteolytic system of Brevibacterium linens and shown the presence of several aminopeptidases. In our study, when $\mathrm{CO}_{2}$ contents higher than $2 \%$ were associated with lower $\mathrm{O}_{2}$ concentration, $B$. aurantiacum growth was decreased; therefore, inducing lower oxido-oxidase activities. The same explanation could be made for $P$. camemberti mycelium growth.

The thickness of the creamy underrind provides information about overall proteolysis and lipolysis of the cheeses. The presence or absence of $\mathrm{CO}_{2}$ on $\mathrm{d} 0$ induced different ripening patterns. Under $2 \mathrm{CO}_{2}$ and $6 \mathrm{CO}_{2}\left(\mathrm{CO}_{2}\right.$ level was not $0 \%$ on $\mathrm{d} 0$ ), the overall ripening measured by the underrind thickness was termed fast-slow, whereas under other conditions $\left(\mathrm{CO}_{2}=0 \%\right.$ on $\left.\mathrm{d} 0\right)$, it was termed slow-fast. However, for a $\mathrm{CO}_{2}$ level above $4 \%$, the cheese underrind was extremely runny on $d$ 40. G. candidum and P. camemberti are well known for their significant lipolytic and proteic systems (Choisy et al., 1997; Boutrou and Guéguen, 2005). The effects of $\mathrm{CO}_{2}$ on their growth (notably $6 \%$ on G. candidum and $2 \%$ on $P$. camemberti mycelia) and on their equilibrium might explain the underrind dynamics. B. aurantiacum is also well known for its important exo- and endocellular proteolytic activities (Lecocq and Guéguen, 1994; Rattray and Fox, 1999), and K. lactis has few endocellular proteolytic activities (Klein et al., 2002). These 2 strains have no significant lipolytic activities in comparison to G. candidum and P. camemberti. However, the important death rate of $K$. lactis in presence of the highest $\mathrm{CO}_{2}$ level could also favor the cheese underrind liquefaction by release of endocellular enzymes in the cheese (Klein et al., 2002). The role B. aurantiacum played was difficult to determine because it grows in the presence of significant $\mathrm{CO}_{2}$ levels when the $\mathrm{O}_{2}$ level was above $12 \%$ in relation to $\mathrm{CO}_{2}$ and $\mathrm{O}_{2}$ levels.

The $\mathrm{CO}_{2}$ atmospheric conditions had an effect on overall cheese ripening. Indeed, high concentrations of $\mathrm{CO}_{2}(>2 \%)$ degraded cheese color and $P$. camemberti mycelium growth as well as cheese shape and underrind quality (texture).

\section{CONCLUSIONS}

Whatever the ripening atmospheric conditions in the chamber, the presence of $\mathrm{CO}_{2}$ resulted in numerous changes in the microbiological and biochemical aspects of the cheeses. It seemed to set in motion some enzymatic dynamics related to G. candidum and $P$. camemberti cells or mycelia that appeared linked to $\mathrm{CO}_{2}$ levels. The higher the $\mathrm{CO}_{2}$ concentration, the higher the $G$. candidum cell concentrations and the poorer the appearance of $P$. camemberti mycelium and cheese appearance (underrind thickness and color). Moreover, the ripening was accelerated in the presence of $\mathrm{CO}_{2}$ on d 0 . The best ripening conditions to obtain an optimum between microorganism growth and biochemical dynamics as well as cheese appearance was around $2 \%$ of $\mathrm{CO}_{2}$ in the presence of an $\mathrm{O}_{2}$ concentration of 17 to $18 \%$. The above results may be helpful if chamber ripening is to be shortened while maintaining the quality of mold soft cheeses.

\section{ACKNOWLEDGMENTS}

This work was supported in part by the French Research Ministry (MENRT, Paris France) and ARILAIT 
(Paris, France). The authors are deeply grateful to Valérie Mirallés for his technical assistance throughout the study. Cristian Trelea's assistance with the statistical analyses is gratefully acknowledged. We also wish to thank Suzette Tanis-Plant for her editorial advice.

\section{REFERENCES}

Adour, L., C. Couriol, A. Amrane, and Y. Prigent. 2002. Growth of Geotrichum candidum and Penicillium camembertii in liquid media in relation with the consumption of carbon and nitrogen sources and the release of ammonia and carbon dioxide. Enzyme Microb. Techn. 31:533-542.

Bonaïti, C., M. N. Leclercq-Perlat, E. Latrille, and G. Corrieu. 2004. Deacidification by Debaryomyces hansenii of smear soft cheeses ripened under controlled conditions: Relative humidity and temperature influences. J. Dairy Sci. 87:3976-3988.

Boutrou, R., and M. Guéguen. 2005. Interests in Geotrichum candidum for cheese technology. Int. J. Food Microbiol. 102:1-20.

Champagne, C. P., L. Soulignac, M. Marcotte, and J.-P. Innocent. 2003. Texture et évolution du $\mathrm{pH}$ de fromages de type Brie entreposés en atmosphère contrôlée. Lait 83:145-151.

Choisy, C., M. J. Desmazeaud, J. C. Gripon, G. Lamberet, and J. Lenoir. 1997. La biochimie de l'affinage. Pages 86-105 in Le fromage. A. Eck and J. C. Gillis, ed. Tec Doc Lavoisier, Paris, France.

Colchin, L. M., S. L. Owens, G. Lyubachevskaya, E. Boyle-Roden, E. Russek-Cohen, and S. A. Rankin. 2001. Modified atmosphere packaged Cheddar cheese shreds: Influence of fluorescent light exposure and gas type on color and production of volatile compounds. J. Agric. Food Chem. 49:2277-2282.

Couriol, L., A. Amarane, and Y. Prigent. 2001. A new model for the reconstruction of biomass history from carbon dioxide emission during batch cultivation of Geotrichum candidum. J. Biosci. Bioeng. 91:570-575.

Doyon, G., J. Gagnon, D. Lafontaine, C. Desilets, and C. P. Champagne. 1997. The effect of carbon dioxide on the growth of Penicillium camemberti. Microbiol. Aliments. Nutr. 15:291-297.

Gavrish, E. Y., V. I. Krauzova, N. V. Potekhina, E. G. Plotnikova, O. V. Altyntseva, L. A. Korosteleva, and L. I. Evtushenko. 2004. Three new species of brevibacteria, Brevibacterium antiquum $\mathrm{sp}$. nov., Brevibacterium aurantiacum sp. nov., and Brevibacterium permense sp. nov. Microbiology 73:176-183.

Gobbetti, M., R. Lanciotti, M. de Angelis, M. R. Corbo, R. Massini, and P. Fox. 1999. Study of the effects of temperature, $\mathrm{pH}, \mathrm{NaCl}$, and aw on the proteolytic and lipolytic activities of cheese-related lactic acid bacteria by quadratic response surface methodology. Enz. Microb. Technol. 25:795-809.

Gripon, J. C. 1993. Mould-ripened cheeses. Pages 111-136 in Cheese: Chemistry, Physics and Microbiology. Vol. 2. P. F. Fox, ed. Chapman Hall, London, UK.

Hardy, J., J. Scher, H. E. Spinnler, E. Guichard, and J. C. Gripon. 2000. Physical and sensory properties of cheese. Pages 447-473 in Cheesemaking: From science to quality assurance. A. Eck and J. C. Gillis, ed. Intercept Limited, Andover, UK.

Hemme, D., C. Bouillanne, F. Metro, and M. J. Desmazeaud. 1982. Microbial catabolism of amino acids during cheese ripening. Sci. Aliments 2:113-123.

Kiermeier, F., and H. Wolfseder. 1972a. Behaviour of packaged cheese. II. Effect of packaging on weight losses of Camembert cheese. Lebensm. Unters. Forsch. 149:218-223.
Kiermeier, F., and H. Wolfseder. 1972b. Behaviour of packaged cheese. III. Effect of packaging on gas-metabolism of Camembert. Lebensm. Unters. Forsch. 149-150:75-83.

Klein, N., A. Zourari, and S. Lortal. 2002. Peptidase activity of four yeast species frequently encountered in dairy products: Comparison with several dairy bacteria. Int. Dairy J. 12:853-861.

Leclercq-Perlat, M. N., F. Buono, D. Lambert, H. E. Spinnler, and G. Corrieu. 2004. Controlled production of Camembert-type cheeses: Part I. Microbiological and physicochemical evolutions. J. Dairy Res. 71:346-354.

Lecocq, J., and M. Guéguen. 1994. Effects of $\mathrm{pH}$ and sodium chloride on the interactions between Geotrichum candidum and Brevibacterium linens. J. Dairy Sci. 77:2890-2899.

Magan, N., and J. Lacey. 1984. Effects of gas composition and water activity on growth of field and storage fungi and their interactions. Trans. Br. Mycol. Soc. 82:305-314.

Nunez, M., A. M. Guillen, M. A. Rodriguez-Marin, A. M. Marcilla, P. Gaya, and M. Medina. 1991. Accelerated ripening of ewes' milk Manchego cheese: The effect of neutral proteinases. J. Dairy Sci. 74:4108-4118.

Picque, D., M. N. Leclercq-Perlat, and G. Corrieu. 2006. Effects of atmospheric composition on respiratory behavior, weight loss, and appearance of Camembert-type cheeses during chamber ripening. J. Dairy Sci. 89:3250-3259.

Pintado, M. E., and F. X. Malcata. 2000a. The effect of modified atmosphere packaging on the microbial ecology in Requeijao, a Portuguese whey cheese. J. Food Process. Preserv. 24:107-124.

Pintado, M. E., and F. X. Malcata. 2000b. Optimization of modified atmosphere packaging with respect to physicochemical characteristics of Requeijao. Food Res. Int. 33:821-832.

Ramet, J. P. 2000. Comparing ripening technology of the various types of cheese. Pages 418-446 in Cheesemaking: From science to quality assurance. A. Eck and J. C. Gillis, ed. Lavoisier Publishing, Paris, France.

Rattray, F. P., and P. F. Fox. 1999. Aspects of enzymology and biochemical properties of Brevibacterium linens relevant to cheese ripening: A review. J. Dairy Sci. 82:891-909.

Roger, B., S. Desobry, and J. Hardy. 1998. Respiration of Penicillium camemberti during ripening and cold storage of semi soft cheese. Lait 78:241-250.

Skjerdal, O. T., H. Sletta, S. G. Flenstad, K. D. Josefsen, D. W. Levine, and T. E. Ellingsen. 1995. Changes in cell volume, growth and respiration rate in response to hyperosmotic stress of $\mathrm{NaCl}$, sucrose and glutamic acid in Brevibacterium lactofermentum and Corynebacterium glutamicum. Appl. Microbiol. Biotechnol. 43:1099-1106.

Sousa, M. J., Y. Ardo, and P. L. H. McSweeney. 2001. Advances in the study of proteolysis during cheese ripening. Int. Dairy J. 11:327-345.

Taniwaki, M. H., A. D. Hocking, J. I. Pitt, and G. H. Fleet. 2001. Growth of fungi and mycotoxin production on cheese under modified atmospheres. Int. J. Food Microbiol. 68:125-133.

van den Tempel, T., and M. S. Nielsen. 2000. Effects of atmospheric conditions, $\mathrm{NaCl}$ and $\mathrm{pH}$ on growth and interactions between moulds and yeasts related to blue cheese production. Int. Food Microbiol. 57:193-199.

von Mrowetz, G. 1979. Kolorimetrische Bestimmung des Ammoniumgehaltes von Käsen. Milchwissenschaft 34:593-597.

Weissenfluh, A., and Z. Puhan. 1987. The influence of the climatic conditions on the growth of Penicillium camemberti and the quality of Camembert cheese. Schweiz. Milchw. Forsch. 16:37-44.

Wells, J. M., and D. H. Spalding. 1975. Stimulation of Geotrichum candidum by low oxygen and high carbon dioxide atmospheres. Phytopathology 65:1299-1302. 